\title{
Transport of Veterinary Antibiotics in Farmland Soil: Effects of Dissolved Organic Matter
}

\author{
Lanre Anthony Gbadegesin ${ }^{1,2}\left(\mathbb{C}\right.$, Xiangyu Tang ${ }^{1,3, *}$, Chen Liu ${ }^{1, *}$ and Jianhua Cheng ${ }^{3}$ \\ 1 Key Laboratory of Mountain Surface Processes and Ecological Regulation, Institute of Mountain Hazards and \\ Environment, Chinese Academy of Sciences, Chengdu 610041, China; lanrex2010@gmail.com \\ 2 International College, University of Chinese Academy of Sciences, Beijing 100049, China \\ 3 State Key Laboratory of Subtropical Silviculture, Zhejiang A\&F University, Hangzhou 311300, China; \\ chengih@zafu.edu.cn \\ * Correspondence: xytang@imde.ac.cn (X.T.); chen1017@imde.ac.cn (C.L.)
}

Citation: Gbadegesin, L.A.; Tang, X.; Liu, C.; Cheng, J. Transport of Veterinary Antibiotics in Farmland Soil: Effects of Dissolved Organic Matter. Int. J. Environ. Res. Public Health 2022, 19, 1702. https:// doi.org/10.3390/ijerph19031702

Academic Editors: Daniela Varrica and Paul B. Tchounwou

Received: 31 December 2021

Accepted: 30 January 2022

Published: 2 February 2022

Publisher's Note: MDPI stays neutral with regard to jurisdictional claims in published maps and institutional affiliations.

Copyright: (C) 2022 by the authors. Licensee MDPI, Basel, Switzerland. This article is an open access article distributed under the terms and conditions of the Creative Commons Attribution (CC BY) license (https:// creativecommons.org/licenses/by/ $4.0 /)$.

\begin{abstract}
The application of manure as a fertiliser to farmland is regarded as a major source of veterinary antibiotic (VA) contamination in the environment. The frequent detection of such emerging contaminants and their potential adverse impacts on the ecosystem and human health have provoked increasing concern for VA transport and fate. Extrinsic dissolved organic matter (DOM) may be introduced into farmland soil along with Vas, and thus exert significant effects on the transport of VAs via hydrological processes upon rainfall. The leaching of VAs can be either enhanced or reduced by DOM, depending on the nature, mobility, and interactions of VAs with DOM of different origins. From the aspect of the diversity and reactivity of DOM, the state-of-the-art knowledge of DOM-VA interactions and their resulting effects on the sorption-desorption and leaching of VAs in farmland soil was reviewed. Spectroscopic techniques for examining the extent of binding and reactive components of DOM with VAs are summarized and their usefulness is highlighted. Models for simulating VA transport under the effects of DOM were also reviewed. It is suggested that distinct impacts of DOM of various organic fertiliser/amendment origins should be considered for predicting the transport of VAs in farmland soil.
\end{abstract}

Keywords: fate; interactions; manure; spectroscopic analyses; transport model

\section{Introduction}

Antibiotics are popularly used in animal husbandry as therapeutics, and to improve livestock productivity. The global average annual antibiotic consumption in cattle, chicken, and pigs was $45 \mathrm{mg} \mathrm{kg}^{-1}, 148 \mathrm{mg} \mathrm{kg}^{-1}$, and $172 \mathrm{mg} \mathrm{kg}^{-1}$, respectively, and the global total antibiotic consumption in food animals was projected to increase by $67 \%$ by 2030 [1]. A significant quantity (40-90\%) of active and unchanged forms of veterinary antibiotics (VAs) administrated to animals are excreted with the urine and faeces of the animals [2,3]. An investigation on the environmental fate of 36 frequently detected antibiotics, including sulfonamides (SAs), tetracyclines (TCs), fluoroquinolones (FQs), macrolides (MLs), $\beta$ lactams, and others, was conducted in China in 2013. The result showed that $84 \%$ of the total antibiotic excretion (54,000 tons) was excreted by animals, mainly pig (44.4\%), chicken $(18.8 \%)$, and other $(20.9 \%)$, and $54 \%$ of the total antibiotic emission (53,800 tons) was received by soil compartments [4]. The application of animal manure as a fertiliser in farmland is a major pathway for VA entrance into the environment (Figure 1) [5,6]. It should be noted that the presence of VAs in manure applied to farmland could instigate the elevated occurrence of antibiotic-resistant genes (ARGs) in soil, which are harboured by pathogenic and/or non-pathogenic microbes [7-12]. Moreover, residual antibiotics in farmland soil and hydrologically connected water bodies could impair ecosystem functions and cause severe contamination of food and drinking water supplies [13]. As such, a full 
understanding of VA transport and fate in soil is of high relevancy with respect to their environmental risk in manured farmland.

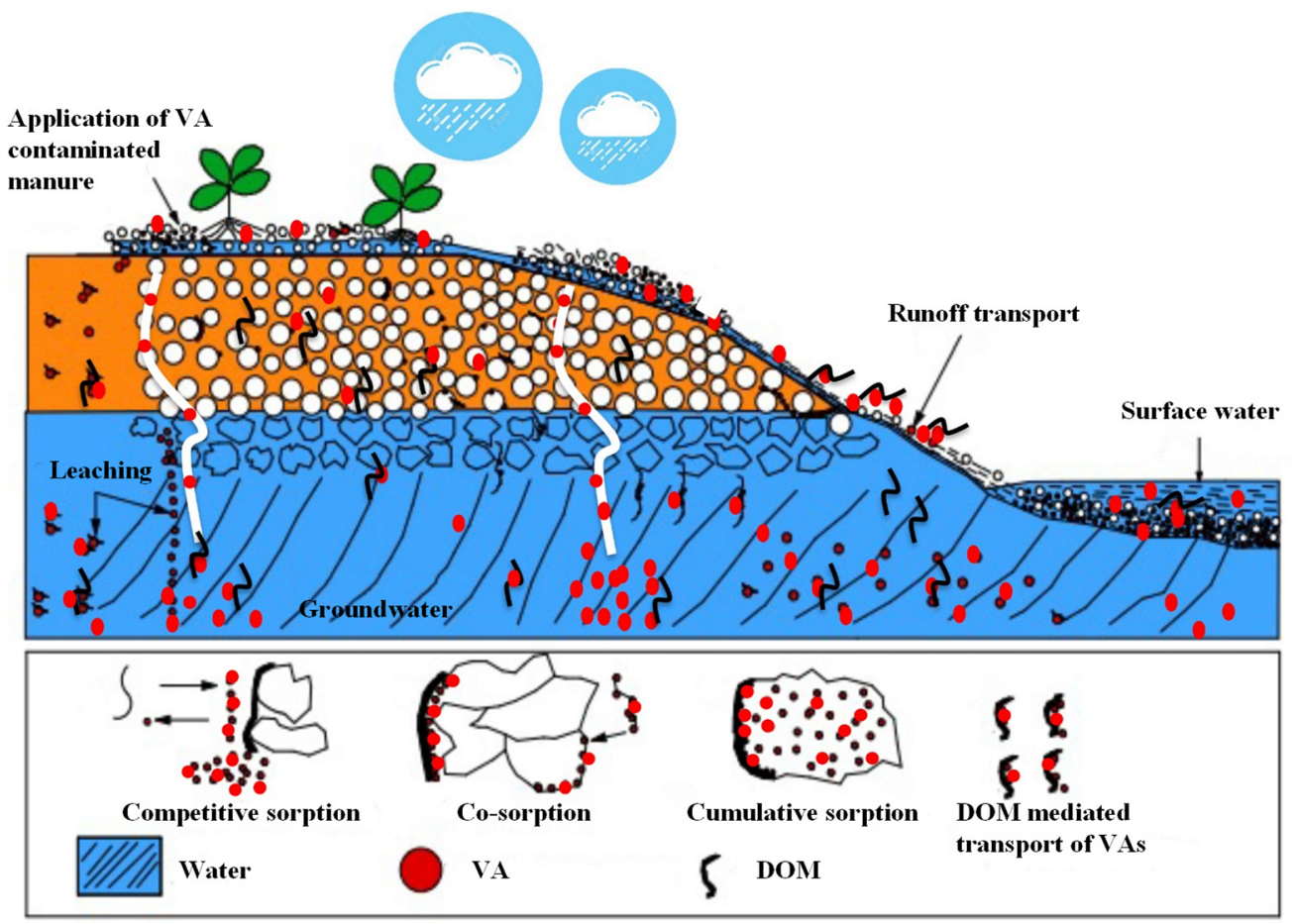

Figure 1. Transport paths of veterinary antibiotics (VAs) via hydrological processes and the mechanisms of potential interactions of VAs with dissolved organic matter (DOM).

Dominant paths of VA transport in farmland soil are runoff and leaching, both of which are dependent on VA sorption to soil, soil hydraulic properties, and precipitation characteristics [14-17]. It is worth noting that the sorption of VAs to the soil matrix can not only reduce their mobility and availability, but also protect antibiotics from degradation [18]. Preferential flow through soil macropores may lead to rapid transport of VAs and other organic pollutants in the subsurface environment $[19,20]$. In addition, natural occurring colloids (e.g., clays, metal oxides, and particulate organics) in farmland soil can act as carriers of Vas, and thus may lead to enhanced VA transport through preferential pathways (e.g., macropores, cracks, and fractures) [21-23]. Notably, the transport of VAs in soil can be strongly influenced by dissolved organic matter (DOM) [24-34], which is operationally defined as the fraction of organic matter that can pass through a $0.45 \mu \mathrm{m}$ filter and is present in the aqueous phase [35-37]. It is regarded as the most active component of soil organic matter due to its diverse chemical structures, functional groups, and molecular sizes $[36,38,39]$. DOM is ubiquitous in the terrestrial environment and can be transported from farmland soils to water bodies through leaching and runoff processes [40,41]. In farmland soils, in addition to soil organic matter, decaying crop straws are the primary natural source of DOM [42]. Furthermore, various soil amendments (e.g., animal manure, biosolid, and biochar) applied to improve soil fertility can also release a substantial amount of DOM into the soil [43,44]. For instance, the application of animal manure may lead to the enrichment of both VAs (excreted with manure) and DOM in the soil $[17,45,46]$, and thus strong interactions between VAs and DOM, which could play a significant role in altering the transport and fate of VAs in the soil $[26,47,48]$. To date, the state-of-the-art knowledge of DOM-VA interactions and their impacts on VA transport have not yet been systematically reviewed.

In this article, a literature review was conducted using different databases (Google Scholar, ScienceDirect, and Web of Science), as well as relevant keywords regarding the following aspects: (1) sources and occurrences of DOM in soil and its influence on sorption- 
desorption and transport of VAs; (2) main mechanisms of DOM-VA interactions; and (3) current mathematical and conceptual models used to describe VAs transport in the presence of DOM. Lastly, future research directions were recommended.

\section{Sources and Occurrences of DOM in Soil}

In farmland, DOM leached from topsoil can be sorbed and thus stored in deep subsoil with a relatively low organic matter content, which is recognized as a carbon reservoir [49-52]. DOM of autochthonous and allochthonous origins differ in properties and biogeochemical behaviour [53,54]. Joint use of multiple techniques to measure DOM properties is necessary, as no single technique is capable of fully characterizing DOMs [55]. Notably, florescence spectroscopy has gained wide acceptance as a technique for measuring DOM moieties in farmland soil (Table S1). Humic-like and tyrosine-like molecules were found to be the major components of DOM in all the dissimilar farmland soils collected from four climate regions in China [56].

Organic soil amendments, such as crop straw, animal manure, compost, biochar, and sewage sludge, can supply the soil with DOM of diverse compositions and contents (e.g., $[54,57,58])$, as shown in Table S1. For instance, crop straw can release a large amount of DOM into farmland soil [59]. According to spectroscopy investigations, fulvic-like, tyrosine-like, humic-like, and tryptophan-like fluorophores are vital components of straw derived DOM (Table S1) $[57,60,61]$. Characteristics of straw derived DOM, including aromaticity, hydrophobicity, and molecular weight, could vary with straw humification time and crop type [59]. Specifically, hydroxyl, carboxyl, amine, and aliphatic C-H are the functional groups of straw-derived DOM that can interact with the soil and organic pollutants $[59,62]$. Animal manure DOM show diverse physicochemical characteristics and chemical structures, depending on the feedstock and composting method $[33,63,64]$. DOM of different animal manure origins may differ in interactions with VAs and thus differ in their effects on their transport in soil $[31,65]$.

DOM interacts with the reactive surface of soil particles, and its transport and leaching behaviour may vary with soil type, landscape, slope, and varying climatic factors $[35,66,67]$. A high affinity of DOM for soil clay surface constrains its movement in the soil [68]. A positive relationship of DOC sorption with iron oxides and the specific surface area of clay minerals (kaolinite < illite < smectite) was reported [69]. The presence of polyvalent exchangeable cations could reduce DOM leaching by enhancing its sorption, mainly through cation bridging between negatively charged clay surfaces and negatively charged anionic functional groups of DOM [51,70-72]. It has been recognized that DOM mobility may affect the fate and transport of antibiotics in soil $[25,33,73,74]$.

\section{Effect of DOM on the Sorption-Desorption of VAs}

DOM is one of the major factors that influence the sorption and transport of VAs in soil $[25,28,31,33,34]$. Table 1 summarises the effects of DOM on the sorption-desorption of VAs reported in the literature. Various mechanisms, including covalent bonding, $\pi-\pi$ interaction, complexation reaction, electrostatic interaction, van der Waals force, hydrophobic partitioning, and pore entrapment, may co-occur in the sorption-desorption process of VAs in a soil-DOM system [24,26,30,31]. The interactions between DOM and VAs strongly depend on the solution $\mathrm{pH}$ and ionization state of VAs [7,30]. The sorption-desorption process may become more complex in the presence of DOM, as it could provide abundant functional groups that are reactive with soil surfaces and VAs. 
Table 1. Effects of various DOM on sorption-desorption of VAs in soils.

\begin{tabular}{|c|c|c|c|c|c|}
\hline DOM Type/Source & Extractant & Sorbate & Sorbent & $\begin{array}{l}\text { Effect of DOM on } \\
\text { Sorption/Desorption }\end{array}$ & Reference \\
\hline Pig manure DOM & Water & Sulfadiazine & Various arable soils & $\begin{array}{l}\text { Manure DOM decreased the sorption } \\
\text { of sulfadiazine to soil due to } \\
\text { competitive sorption. }\end{array}$ & [75] \\
\hline $\begin{array}{l}\text { Commercial humic } \\
\text { acid (HA) }\end{array}$ & $\mathrm{NaOH}$ solution & Sulfamethoxazole & Crop straw biochar & $\begin{array}{l}\text { HA intensified the sorption and } \\
\text { desorption of sulfamethoxazole, and } \\
\text { the dominant mechanism depended } \\
\text { on HA concentration, sorbate } \\
\text { properties, and the adlayer effects. }\end{array}$ & [76] \\
\hline Soil organic matter & NA & Sulfanilamide & Soil & $\begin{array}{l}\text { Sulfanilamide binding increased with } \\
\text { increasing the soil organic matter } \\
\text { polarity. }\end{array}$ & [77] \\
\hline $\begin{array}{l}\text { Manure and compost } \\
\text { DOM }\end{array}$ & NA & Sulfamethoxazole & Soil & $\begin{array}{l}\text { Sulfamethoxazole extractability } \\
\text { decreased with increasing the } \\
\text { complexity of co-extracted DOM over } \\
\text { a wide incubation time. }\end{array}$ & [78] \\
\hline Peak soil & $\mathrm{NaOH}$ solution & Sulfamethazine & Humin & $\begin{array}{l}\text { Humin increased sulfamethazine } \\
\text { sorption, and the sorption strength } \\
\text { increased with the progressive } \\
\text { removal of ash, O-alkyl carbon, lipid, } \\
\text { and lignin components from humin. }\end{array}$ & [79] \\
\hline Commercial DOM & $\mathrm{CaCl}_{2}$ solution & Sulfamethazine & Crop straw biochar & $\begin{array}{l}\text { Sulfamethazine sorption to biochar } \\
\text { decreased with increasing the HA } \\
\text { concentration through surface } \\
\text { modification, and competitive } \\
\text { sorption/pore blockage, but the } \\
\text { effects depended on the chemical } \\
\text { properties of DOM, biochar properties, } \\
\text { and nature of antibiotic species. }\end{array}$ & [48] \\
\hline Soil HA & NA & $\begin{array}{l}\text { Tetracycline and } \\
\text { Clarithromycin }\end{array}$ & DOM & $\begin{array}{l}\text { Tetracycline and clarithromycin } \\
\text { strongly bound to DOM, but the } \\
\text { solution pH and ionic strength } \\
\text { influenced the binding interaction. }\end{array}$ & [80] \\
\hline Soil DOM & $\mathrm{CaCl}_{2}$ solution & Tetracycline & Arable field topsoil & $\begin{array}{l}\text { Presence of DOM caused significant } \\
\text { sorption by enhancing the transfer of } \\
\text { tetracycline from liquid phase to solid } \\
\text { soil particles. }\end{array}$ & [81] \\
\hline $\begin{array}{l}\text { Plant and chicken } \\
\text { manure derived } \\
\text { DOM }\end{array}$ & Water & Oxytetracycline & Sediment & $\begin{array}{l}\text { Plant-origin DOM (mainly } \\
\text { humus-like) promoted oxytetracycline } \\
\text { sorption, while chicken DOM (mainly } \\
\text { protein-like) inhibited the sorption of } \\
\text { oxytetracycline. }\end{array}$ & [82] \\
\hline $\begin{array}{l}\text { Wastewater } \\
\text { treatment plant } \\
\text { effluent DOM }\end{array}$ & NA & $\begin{array}{l}\text { Sulfonamides } \\
\text { (sulfapyridine, } \\
\text { sulfameter, and } \\
\text { sulfadimethoxine) } \\
\text { and trimethoprim }\end{array}$ & Agricultural soils & $\begin{array}{l}\text { Presence of DOM lowered the linear } \\
\text { distribution coefficient }\left(K_{d}\right) \text { of the } \\
\text { tested antibiotics in soils. }\end{array}$ & [46] \\
\hline Exogenous DOM & $\mathrm{CaCl}_{2}$ solution & $\begin{array}{l}\text { Sulfamethoxazole, } \\
\text { sulfamethazine, } \\
\text { and sulfadiazine }\end{array}$ & $\begin{array}{l}\text { Soil with/without } \\
\text { biochar } \\
\text { amendment }\end{array}$ & $\begin{array}{l}\text { DOM decreased the sorption of the } \\
\text { three target antibiotics to biochar } \\
\text { amended soils. }\end{array}$ & [83] \\
\hline Commercial DOM & NA & $\begin{array}{l}\text { Tylosin and } \\
\text { sulfamethazine }\end{array}$ & HA & $\begin{array}{l}\text { Tylosin and sulfamethazine were } \\
\text { strongly sorbed to HA through cation } \\
\text { exchange and } \pi-\pi \text { EDA interaction } \\
\text { mechanisms. }\end{array}$ & [84] \\
\hline $\begin{array}{l}\text { Fresh and aged } \\
\text { soil-biochar mixture }\end{array}$ & $\mathrm{CaCl}_{2}$ solution & $\begin{array}{l}\text { Oxytetracycline } \\
\text { and florfenicol }\end{array}$ & $\begin{array}{l}\text { Soil with/without } \\
\text { biochar } \\
\text { amendment }\end{array}$ & $\begin{array}{l}\text { Biochar released DOM reduced } \\
\text { oxytetracycline sorption to soil } \\
\text { through competitive sorption while it } \\
\text { increased florfenicol sorption through } \\
\text { hydrophilic partitioning. }\end{array}$ & [85] \\
\hline
\end{tabular}


Table 1. Cont.

\begin{tabular}{|c|c|c|c|c|c|}
\hline DOM Type/Source & Extractant & Sorbate & Sorbent & $\begin{array}{l}\text { Effect of DOM on } \\
\text { Sorption/Desorption }\end{array}$ & Reference \\
\hline Wastewater DOM & NA & Sulfadimidine & $\begin{array}{l}\text { DOM solutions } \\
\text { with/without } \\
\text { ozonation }\end{array}$ & $\begin{array}{l}\text { Strong complexation of sulfadimidine } \\
\text { with DOM was enhanced by } \\
\text { protein-like DOM components } \\
\text { (tryptophan-like and tyrosine-like). }\end{array}$ & [86] \\
\hline Surface water DOM & NA & $\begin{array}{l}\text { Sulfamethoxazole } \\
\text { and clarithromycin }\end{array}$ & Natural DOM & $\begin{array}{l}\text { An insignificant binding interaction } \\
\text { was observed for the antibiotics due } \\
\text { to their lower hydrophobicity and } \\
\text { weak acid groups. }\end{array}$ & [87] \\
\hline $\begin{array}{l}\text { Sediment derived } \\
\text { HA }\end{array}$ & $\mathrm{NaOH}$ solution & Ofloxacin & DOM & $\begin{array}{l}\text { Nonlinear binding interactions } \\
\text { between ofloxacin and DOM } \\
\text { dominated, which involved } \\
\text { H-bonding, electrostatic interactions, } \\
\text { and cation exchange. }\end{array}$ & [88] \\
\hline $\begin{array}{l}\text { Phytoplankton and } \\
\text { macrophyte derived } \\
\text { DOM }\end{array}$ & Water & Sulfamethazine & Goethite & $\begin{array}{l}\text { An increasing concentration of DOM } \\
\text { facilitated the sulfamethazine sorption } \\
\text { on goethite, which was more } \\
\text { significant in DOM dominated by } \\
\text { protein-like substances. }\end{array}$ & [89] \\
\hline $\begin{array}{l}\text { Crop straw biochar } \\
\text { derived DOM }\end{array}$ & Water & $\begin{array}{l}\text { Sulfamethoxazole } \\
\text { and } \\
\text { chloramphenicol }\end{array}$ & Biochars & $\begin{array}{l}\text { DOM concentration modulated } \\
\text { antibiotic sorption depending on the } \\
\text { proportions of fulvic and HA-like } \\
\text { DOM components. }\end{array}$ & [90] \\
\hline $\begin{array}{l}\text { Composted biosolid } \\
\text { derived DOM }\end{array}$ & Water & Sulfapyridine & Agricultural soils & $\begin{array}{l}\text { Co-introduction of DOM with } \\
\text { sulfapyridine significantly reduced its } \\
\text { sorption to soils, and DOM precoated } \\
\text { soil exhibited both cumulative } \\
\text { sorption and reduced sorption. }\end{array}$ & {$[25]$} \\
\hline Poultry litter DOM & Water & Sulfamethazine & $\begin{array}{l}\text { Soils of different } \\
\text { land use types }\end{array}$ & $\begin{array}{l}\text { Competitive interactions occurred } \\
\text { between sulfamethazine and DOM } \\
\text { (>1000 Da), leading to reduced } \\
\text { sulfamethazine sorption to soil. }\end{array}$ & [91] \\
\hline $\begin{array}{l}\text { Wastewater effluent } \\
\text { DOM }\end{array}$ & NA & Tetracycline & Soil & $\begin{array}{l}\text { Tetracycline sorption to soil decreased } \\
\text { with increasing the HA concentration } \\
\text { due to the high mobility and } \\
\text { competitive sorption. }\end{array}$ & {$[92]$} \\
\hline $\begin{array}{l}\text { Decayed plant and } \\
\text { composted manure } \\
\text { derived DOM }\end{array}$ & Water & Oxytetracycline & Sediments & $\begin{array}{l}\text { Decayed plant-derived DOM } \\
\text { promoted oxytetracycline sorption, } \\
\text { while manure DOM exhibited } \\
\text { inhibitory effects. DOM concentration } \\
\text { modulated antibiotic sorption. }\end{array}$ & [93] \\
\hline Commercial HA & $\mathrm{NaOH}$ solution & Ofloxacin/flumequir & Kaolinite & $\begin{array}{l}\text { Presence of DOM enhanced the } \\
\text { co-precipitation of } \\
\text { ofloxacin/flumequine from aqueous } \\
\text { phase, but the effects varied } \\
\text { depending on pH. }\end{array}$ & {$[94]$} \\
\hline
\end{tabular}

Note: NA = not applicable.

DOM may have opposite effects on VA sorption to soil [73] (Figure 1). For instance, the addition of manure DOM was reported to decrease sorption $K_{\mathrm{f}}$ (the sorption coefficient of the Freundlich model) of chlortetracycline, tylosin, and sulfadiazine to soil, while it increased the sorption $K_{\mathrm{f}}$ of sulfamethazine [75,95]. DOM can form complexes with VAs and the complexes may be sorbed onto soil surface, which is a process termed "co-sorption"; DOM may also occupy the active sites on the soil matrix and thus provide additional sorption sites for VA sorption through its multiple moieties, which is a process termed "cumulative sorption" $[62,96,97]$. For instance, significant increases in the sorption $K_{d}$ (the distribution coefficient of the linear model) of ciprofloxacin and tetracycline caused by coating the soils with humic acids (HAs) were observed [98]. A marked decrease in the sorption $q_{\max }$ (the maximum sorption capacity of the Langmuir model) of tetracycline from $5241 \mathrm{mg} \mathrm{kg}^{-1}$ to $1274 \mathrm{mg} \mathrm{kg}^{-1}$ was observed after DOM had been extracted from the 
soil [81]. It was found that the addition of straw derived DOM could cause an increase in the sorption $q_{\max }$ of sulfamethoxazole by 2.6 times [62]. Contrastingly, DOM may restrict VAs from being sorbed to the soil surface by inducing a masking effect that repels or desorbs VAs from the solid phase into the solution phase, which is a process termed "competitive sorption" $[51,99,100]$. For instance, the pre-sorption and co-introduction of DOM in soils with low organic matter contents $(<0.15 \%)$ was found to result in enhanced desorption of sulfapyridine. Similarly, a decrease in the sorption $K_{\mathrm{f}}$ of florfenicol by about $23 \%$ was observed upon the addition of manure-derived DOM, as compared to treatments without DOM [34]. Overall, the varying sorption-desorption behaviours of VAs in the presence of DOM are dependent on the physicochemical properties (e.g., molecular weight, aromaticity, and hydrophobicity) of DOM and soil properties, as well as the solution condition (e.g., $\mathrm{pH}$ and salts) $[56,62]$.

\section{Effect of DOM on the Transport of VAs}

DOM can be regarded as reactive and mobile organic colloids. The presence of DOM colloids may enhance the transport of VAs in soil via two main mechanisms: DOM can form complexes/association with VAs in a solution and thus increase the desorption of VAs from solid phase into pore water. On the other hand, DOM may also be preferentially sorbed to soil particles and thus occupy the available sorption sites, leading to increased release and leaching of VAs from the soil system into the groundwater $[33,34]$. For instance, DOM of different manure sources was reported to facilitate sulfamoxole leaching in the presence of highly mobile manure DOM, mainly as a result of the competitive sorption of DOM with sulfamoxole for the sorption sites [33]. Similarly, co-transport of dairy manure DOM and chlortetracycline reportedly increased the mass recovery (from $2.1 \%$ to $4.3 \%$ ) and reduced the retardation factors (from 890 to 371) of chlortetracycline, which was also attributed to competitive sorption [95]. Aside from the DOM of a manure origin, soil-derived HA can also significantly enhance the transport of tetracycline by more than $10 \%$ through competitive sorption [101]. Likewise, the recovery rate of ciprofloxacin was reported to increase by $32.7 \%$ in soil coated with soil-derived HA, while tetracycline recovery increased from $13.8 \%$ to $33.2 \%$ in the presence of soil colloids [98]. Contrastingly, retardation of sulfadiazine and sulfamethoxypyridazine was observed when manure DOM was added, due to their high sorption affinity to the sorbed DOM on soil [33]. In addition, the preloading of natural DOM in soil columns could facilitate the transport of nalidixic acid (a quinolone antibiotic), which was attributed to enhanced retardation through hydrophobic and $\pi-\pi$ interactions [102]. DOM could have opposite effects on the breakthrough curve of VAs in a homogenous repacked soil column, depending on the nature of the interactions of DOM with soils and VAs (Figure 2).

Among the VA groups, SAs and TCs are ubiquitous in surface water and groundwater due to their hydrophilicity and high mobility, although their interactions with DOM can alter their fate and sorption to the solid surface. For instance, a field investigation in an intensive agricultural and livestock production area showed that remarkable concentrations of SAs in groundwater were associated with aliphatic and unsaturated oxygen-poor constituents of DOM, while the presence of TCs were related to the unsaturated highoxygen-rich constituents of DOM [103]. Manure DOM with a high content of hydrophobic compounds, protein $\mathrm{C}, \mathrm{SUVA}_{280}$, and a low $\mathrm{C} / \mathrm{N}$ ratio was reported to enhance the leaching of sulfamoxole [33]. These studies highlighted the significance of the chemical nature of DOM and VAs in DOM-VA interactions and VA transport in soils. 


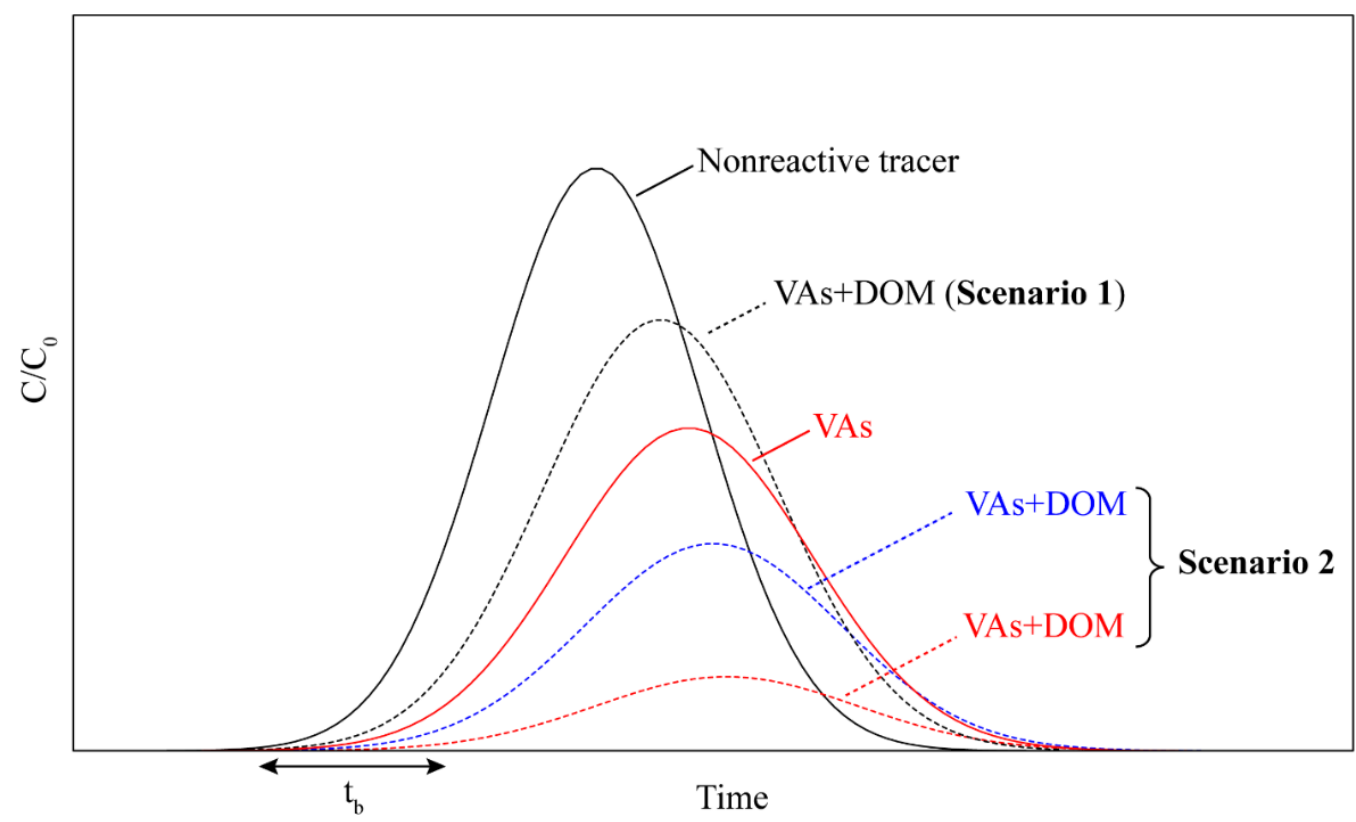

Figure 2. Schematic diagram showing contrasting hypothetical breakthrough curves (BTCs) of nonreactive tracer and veterinary antibiotics (VAs) in the presence and absence of dissolved organic matter (DOM) through homogeneous soil columns. Scenario 1: facilitated transport of VAs through mechanisms such as co-transport, competitive sorption, and colloid facilitated transport. Scenario 2: retardation of VAs through mechanisms such as co-sorption, cumulative sorption, complexation reaction, and straining/pore-entrapment of mobile colloids bearing VAs. $t_{\mathrm{b}}$ and $C / C_{0}$ are breakthrough time and relative concentration, respectively.

In addition to leaching, offsite effects of VAs via runoff transport have attracted considerable environmental concerns. As illustrated in Figure 1, antibiotics released from manure-fertilised farmlands after rainfall or irrigation can be transported via runoff to low-land areas and surface waters. VAs, including TCs, SAs, and MLs, have been detected in runoff and surface water $[14,104,105]$. For example, in a tramline plot experiment, 703.2 and $71.1 \mu \mathrm{g} \mathrm{L}^{-1}$ of SAs and TCs, respectively, were detected in runoff water from the plots treated with animal slurry [105]. Likewise, oxytetracycline and chlortetracycline were detected in runoff transport from an irrigated pasture in ranges of 1-700 and 1-1300 $\mathrm{ng} \mathrm{L}^{-1}$, respectively; furthermore, contents of VAs in the range of $1-24 \mu \mathrm{g} \mathrm{kg}^{-1}$ were detected in the upper $5 \mathrm{~cm}$ soil below the manure pat [14].

\section{Characterisation of DOM-VA Interactions in Soil-Water Systems}

Spectroscopic analyses of DOM-VA binding interactions have been undertaken in a few previous studies.

\subsection{Functional Properties of DOM}

Hydrophobicity and molecular weight are two important functional properties of DOM affecting its interactions with VAs in the environment [106]. DOM can be operationally fractionated into two major parts based on hydrophobic-hydrophilic characteristics $[106,107]$. XAD resin is a broadly used technique $[107,108]$ to separate DOM based on their sorption properties. Hydrophobic-hydrophilic fractions of DOM were found to play a significant role in governing the fate of organic pollutants in soil, including pharmaceuticals [106].

Molecular weight distribution of DOM is an essential property in monitoring of pollutant distribution, persistence, and transport in natural water and soil $[109,110]$. Size exclusion chromatography (SEC) can be used in combination with high-performance liquid chromatography (HPLC) to fractionate DOM based on molecular size [111,112]. DOM con- 
tains high molecular weight substances (humic and fulvic acid), as well as low molecular weight substances (proteins, organic acids, carbohydrates, and other compounds) [108]. Diverse molecular properties of DOM are responsible for its significant reactive nature in the environment [111,113]. For example, the binding capacity of large size DOM fractions (>100 kDa and 10-100 kDa) to FQs was found to be lower than that of smaller size DOM fractions [114]. Likewise, the binding capacities of DOM size fractions to TCs (tetracycline, oxytetracycline, and chlortetracycline) in the order of $30 \mathrm{kDa}-0.45 \mu \mathrm{m}>5-30 \mathrm{kDa}>$ below $1 \mathrm{kDa}>1-5 \mathrm{kDa}$ was observed, indicating that the fractions of $30 \mathrm{kDa}-0.45 \mu \mathrm{m}$ and 5-30 kDa could facilitate the transport of TCs [27].

\subsection{Spectroscopic Properties of DOM}

Spectroscopic methods have been extensively used for the chemical and structural characterisation of DOM due to their accuracy and ability to give a detailed molecular structure of DOM [44,115], and have shown much usefulness in elucidating the interactions between DOM and VAs, especially in water $[29,31,32,81,89,116,117]$.

\subsubsection{Ultraviolet and Fluorescence Spectroscopy of DOM}

Ultraviolet and visible (UV-VIS) absorbance has been widely used to characterise DOM as a non-destructive and inexpensive method [118]. It reflects the carboxylic and aromatic chromophores of DOM based on the absorbance wavelength [113], and absorbance ratios such as $\mathrm{A}_{254} / \mathrm{A}_{204}, \mathrm{~A}_{254} / \mathrm{A}_{436}$, and $\mathrm{A}_{250} / \mathrm{A}_{365}$ are correlated with DOM reactive properties and thus valuable for DOM characterisation $[31,113,119,120]$. UV-VIS absorbance is often used together with a three-dimensional fluorescence excitation-emission matrix (3D-EEM) to comprehensively describe DOM-VA interactions $[31,89,117]$.

Fluorescence EEM spectroscopy provides valuable insights into DOM-VA interactions by revealing changes in the fluorescence peak intensities of interacting compounds (Table 2). EEM fluorescence peaks may contain five regions, which represent tyrosine, tryptophan, and HA-like organics [121], and were debatably attributed to carboxyl, phenolic hydroxyl, or carbonyl groups, respectively [122]. These fluorescent components of DOM play crucial roles in DOM-VA interaction [123]. Fluorescence quenching may occur when DOM interacts with the VA molecule and suppresses its energy emission [124]. Such a quenching process may lead to energy transfer or to the formation of a ground-state complex, which is commonly referred to as dynamic or static quenching, respectively [82,123]. Static quenching implies that DOM-VA binding or complexation leads to a significant decrease in freely dissolved VAs in soil, while dynamic quenching results from charge transfer that occurs when fluorophore and quencher collided [26,29,31,117]. The complexation and binding properties of DOM-VA interactions were found to be highly related to the proportion of DOM fluorescent components [31,117]. 
Table 2. A summary of the findings on DOM-VA interactions using various spectroscopic techniques.

\begin{tabular}{|c|c|c|c|c|c|}
\hline Interaction & DOM Concentration & VA Concentration & Spectroscopic Method & Finding & Reference \\
\hline $\begin{array}{l}\text { Fluoroquinolones } \\
\text { (ciprofloxacin, enoxacin, } \\
\text { ofloxacin, norfloxacin) and } \\
\text { DOM }\end{array}$ & $0-2.8 \mathrm{mg} \mathrm{L}^{-1}$ & $1.8 \mathrm{mg} \mathrm{L}^{-1}$ & $\begin{array}{l}\text { Nuclear magnetic resonance } \\
\text { (NMR) spectroscopy, } \\
\text { fluorescence quenching, } \\
\text { UV-VIS spectroscopy, and } \\
\text { Fourier transform infrared } \\
\text { (FTIR) spectroscopy }\end{array}$ & $\begin{array}{l}\text { A static and exothermic binding interaction occurred } \\
\text { between FQs and humic acid (HA). H-bonding, } \\
\text { electrostatic effect, van der Waals force, and } \pi-\pi \\
\text { stacking were involved. The aromatic ring and } \\
\text { double bond proton were the central binding region } \\
\text { for HA. The main DOM functional groups involved } \\
\text { were O-H, C-H, -COOH, and N-H. }\end{array}$ & [31] \\
\hline Sulfamethazine and DOM & $20 \mathrm{mg}^{-\mathrm{C} \mathrm{L} \mathrm{L}^{-1}}$ & $0-25 \mathrm{mg} \mathrm{L}^{-1}$ & $\begin{array}{l}\text { Fluorescence } \\
\text { excitation-emission matric } \\
\text { spectroscopy combined with } \\
\text { parallel factor analysis } \\
\text { (EEM-PARAFAC) }\end{array}$ & $\begin{array}{l}\text { Static fluorescence quenching dominated the } \\
\text { sulfamethazine-DOM interaction. The protein-like } \\
\text { component of DOM formed the strongest binding } \\
\text { interaction with sulfamethazine with about } 95-100 \% \\
\text { quenched, while the humic-like quenched was about } \\
68-86 \% \text {. The interaction of sulfamethazine with DOM } \\
\text { components followed the order: tryptophan- > } \\
\text { tyrosine- > humic-like component. The binding } \\
\text { affinity of sulfamethazine to protein-like and } \\
\text { humic-like DOM components were } 2.75-4.25 \text { and } \\
2.06-2.78 \text {, respectively. }\end{array}$ & [24] \\
\hline $\begin{array}{l}\text { Fluoroquinolones } \\
\text { (ciprofloxacin, enoxacin, } \\
\text { fleroxacin, levofloxacin, } \\
\text { norfloxacin, and ofloxacin) } \\
\text { and DOM (HA) }\end{array}$ & $0-2.5 \mathrm{mg} \mathrm{L}^{-1}$ & $3.0 \times 10^{-5} \mathrm{M}$ & Fluorescence quenching & $\begin{array}{l}\text { Static quenching occurred in DOM-FQ interactions, } \\
\text { and equilibrium binding constants were }<1 \text { for all the } \\
\text { FQs, indicating a weak binding interaction due to the } \\
\text { high solubility nature of the FQs and the weak } \\
\text { H-bonding. }\end{array}$ & [24] \\
\hline Tetracycline and DOM & $15 \mathrm{mg} \mathrm{L}^{-1}$ & $0-60 \mu \mathrm{mol} \mathrm{L}-1$ & $\begin{array}{l}\text { Fluorescence } \\
\text { EEM-PARAFAC, } \\
\text { synchronous fluorescence } \\
\text { spectra combined with } \\
\text { two-dimensional correlation } \\
\text { spectroscopy (2D-COS), } \\
\text { UV-VIS spectroscopy, and } \\
\text { FTIR spectroscopy }\end{array}$ & $\begin{array}{l}\text { Static quenching followed by complexation occurred } \\
\text { in DOM-tetracycline interactions in the order of } \\
\text { tryptophan-like }>\text { tyrosine-like }>\text { humic-like } \\
\text { component. Amide I and II, aromatics, and aliphatics } \\
\text { were the main functional groups responsible for the } \\
\text { interactions. }\end{array}$ & [89] \\
\hline
\end{tabular}


Table 2. Cont.

\begin{tabular}{|c|c|c|c|c|c|}
\hline Interaction & DOM Concentration & VA Concentration & Spectroscopic Method & Finding & Reference \\
\hline Ofloxacin and dissolved HA & $25 \mathrm{mg}^{-\mathrm{C} \mathrm{L}^{-1}}$ & $50-200 \mathrm{mg} \mathrm{L}^{-1}$ & $\begin{array}{l}\text { Fluorescence quenching and } \\
\text { FTIR spectroscopy }\end{array}$ & $\begin{array}{l}\text { The interaction between ofloxacin and dissolved HA } \\
\text { involved a combination of static and dynamic } \\
\text { quenching. The dominant mechanism depended on } \\
\text { the abundance of carboxyl groups in dissolved HA. } \\
\text { Electrostatic interactions and cation exchange were } \\
\text { the main mechanisms. }\end{array}$ & [29] \\
\hline $\begin{array}{l}\text { Four antibiotics (roxarsone, } \\
\text { sulfaquinoxaline, } \\
\text { oxytetracycline, and } \\
\text { erythromycin) and DOM }\end{array}$ & - & $0.5-4.0 \mathrm{mg} \mathrm{L}^{-1}$ & Fluorescence EEM-PARAFAC & $\begin{array}{l}\text { DOM-antibiotic interaction caused significant } \\
\text { quenching of DOM fluorophore and eventual } \\
\text { complexation reaction. The interaction followed the } \\
\text { order: tyrosine } \geq \text { tryptophan }>\text { HA component. }\end{array}$ & [117] \\
\hline Tetracycline and DOM & - & $5-50 \mathrm{mg} \mathrm{L}^{-1}$ & $\begin{array}{l}\text { Fluorescence EEM, } \\
\text { synchronous fluorescence, } \\
\text { 2D-COS, and FTIR } \\
\text { spectroscopy }\end{array}$ & $\begin{array}{l}\text { DOM-tetracycline interaction led to static } \\
\text { fluorescence quenching. The binding order was: } \\
\text { tryptophan-like > tryptophan-like > humic-like } \\
\text { substance. Non-fluorescence components, including } \\
\text { polysaccharide-like substance and aliphatic } \\
\text { compound, were also involved. }\end{array}$ & [81] \\
\hline $\begin{array}{l}\text { Tetracyclines (Tetracycline, } \\
\text { oxytetracycline and } \\
\text { chlortetracycline) and DOM }\end{array}$ & $534.4 \mathrm{mg} \mathrm{L}^{-1}$ & $0.17-0.26 \mathrm{mg} \mathrm{L}^{-1}$ & $\begin{array}{l}\text { Fluorescence EEM combined } \\
\text { with the fluorescence regional } \\
\text { integration (FRI) method, } \\
\text { FTIR spectroscopy, and } \\
\text { UV-VIS spectroscopy }\end{array}$ & $\begin{array}{l}\text { Larger molecular fractions of DOM significantly } \\
\text { influenced the phase distribution of TCs due to the } \\
\text { variation in their physiochemical properties. Surface } \\
\text { complexation, hydrogen bonding, and electrostatic } \\
\text { interactions were dominant mechanisms. The } \\
\text { complexation with TCs followed the order: fulvic > } \\
\text { protein-like> HA-like component. }\end{array}$ & [27] \\
\hline Sulfamethazine and HA & $0.13-2.88 \mathrm{mg} \mathrm{L}^{-1}$ & $0.5 \mathrm{mg} \mathrm{L}^{-1}$ & $\begin{array}{l}\text { Surface plasmon resonance } \\
\text { combined with isothermal } \\
\text { titration microcalorimetry } \\
\text { technologies }\end{array}$ & $\begin{array}{l}\text { Stable and strong binding interaction between HA } \\
\text { and sulfamethazine occurred through hydrogen } \\
\text { bonding, electrostatic interaction, and hydrophobic } \\
\text { interactions. }\end{array}$ & [32] \\
\hline $\begin{array}{l}\text { Oxytetracycline, sulfadiazine, } \\
\text { and HA }\end{array}$ & $200 \mathrm{mg} \mathrm{L}^{-1}$ & $1.5-9.0 \mathrm{mg} \mathrm{L}^{-1}$ & Fluorescence EEM & $\begin{array}{l}\text { Interactions between } \mathrm{HA} \text { and antibiotics led to the } \\
\text { formation of complexes through H-bonding and van } \\
\text { der Waals force, as reflected by the observed static } \\
\text { quenching. }\end{array}$ & [82] \\
\hline
\end{tabular}


Table 2. Cont.

\begin{tabular}{|c|c|c|c|c|c|}
\hline Interaction & DOM Concentration & VA Concentration & Spectroscopic Method & Finding & Reference \\
\hline Ofloxacin and DOM & $5-40 \mathrm{mg} \mathrm{L}^{-1}$ & $3 \mathrm{mg} \mathrm{L}^{-1}$ & $\begin{array}{l}\text { Fluorescence quenching } \\
\text { technology, elemental } \\
\text { characterization, and infrared } \\
\text { spectrum }\end{array}$ & $\begin{array}{l}\text { The DOM-ofloxacin interaction involved static and } \\
\text { dynamic quenching. The binding interaction } \\
\text { increased with decreasing the HA polarity. DOM } \\
\text { hydrophobicity played a significant role in the } \\
\text { interaction. }\end{array}$ & {$[26,88]$} \\
\hline Tetracycline and HA & $5-50 \mathrm{mg} \mathrm{L}^{-1}$ & $0-20 \mathrm{mg} \mathrm{L}^{-1}$ & $\begin{array}{l}\text { Fluorescence EEM combined } \\
\text { with FRI method and } \\
\text { molecular docking }\end{array}$ & $\begin{array}{l}\text { HA formed strong complexes with tetracycline } \\
\text { through electrostatic forces and proton-affinity sites. } \\
\text { Other intermolecular interactions involved were } \\
\text { hydrogen bond, van der Waals, electrostatics, and } \\
\text { torsional forces. }\end{array}$ & [92] \\
\hline Tetracycline and HA & $0.25 \mathrm{~g} \mathrm{~L}^{-1}$ & $5 \mu \mathrm{M}$ & FTIR, NMR, and 2D-COS & $\begin{array}{l}\text { Tetracycline strongly bound to HA. Carboxyl and } \\
\text { phenolic hydroxyl groups in HA and }-\mathrm{N}\left(\mathrm{CH}_{3}\right)_{2} \\
\text { groups of tetracycline were engaged in the interaction. } \\
\text { The binding interaction reduced the degradation of } \\
\text { tetracycline. }\end{array}$ & [125] \\
\hline $\begin{array}{l}\text { Enrofloxacin, DOM (humic } \\
\text { acid and fluvic acid) and } \\
\text { montmorillonite }\end{array}$ & $1 \mathrm{~g} \mathrm{~L}^{-1}$ & $27.8 \mu \mathrm{M}$ & $\begin{array}{l}\text { Attenuated total } \\
\text { reflection-Fourier transform } \\
\text { infrared spectroscopy and } \\
\text { 2D-COS }\end{array}$ & $\begin{array}{l}\text { Enrofloxacin was sorbed to montmorillonite through } \\
\text { cation exchange, proton transfer, electrostatic } \\
\text { interaction, H-bonding, and } \pi-\pi \text { interactions, } \\
\text { depending on solution } \mathrm{pH} \text {. }\end{array}$ & [126] \\
\hline Tetracycline and HA & $2.3,23$, and $46 \mathrm{mg}^{-\mathrm{C} \mathrm{L}^{-1}}$ & $5-100 \mathrm{mg} \mathrm{L}^{-1}$ & $\begin{array}{l}\text { X-ray diffraction and FTIR } \\
\text { spectroscopy }\end{array}$ & $\begin{array}{l}\text { HA-tetracycline interaction reduced tetracycline } \\
\text { mobility through complexation. The main mechanism } \\
\text { involved was electrostatic interaction between } \\
\text { tetracycline (cationic or zwitterionic species) and } \\
\text { carboxylic groups in HA. }\end{array}$ & [30] \\
\hline $\begin{array}{l}\text { Sulfamethoxazole, } \\
\text { clarithromycin, and DOM }\end{array}$ & $0-15 \mathrm{mg} \mathrm{L}^{-1}$ & 10 and $20 \mu \mathrm{g} \mathrm{mL}^{-1}$ & $\begin{array}{l}\text { Cellulose ester dialysis } \\
\text { membranes separation and } \\
\text { LC-MS/MS analysis }\end{array}$ & $\begin{array}{l}\text { DOM-binding through hydrophobic interaction was } \\
\text { not observed for the two antibiotics. }\end{array}$ & [87] \\
\hline
\end{tabular}


Different DOM components behave differently in their binding interactions with VAs. The protein-like components of DOM can form strong binding interactions with VAs $[24,82,127]$. For example, compared to humic-like components, the protein-like (tyrosine and tryptophan) component of DOM from various sources binds more strongly with TCs, sulfamethazine, sulfaquinoxaline-sodium, oxytetracycline, and erythromycin, through multiple molecular binding sites accessible in this component $[24,81,117]$. As such, the fluorescence EEM spectroscopy technique has gained wide acceptance for studying DOM-VA interactions $[24,81,114,115,127-130]$.

\subsubsection{FTIR and NMR Spectroscopy}

The DOM functional groups participating in DOM-VA interactions can be investigated using FTIR in combination with other spectroscopy methods [29,31,81,89]. Moreover, FTIR spectroscopy can be used to reveal the non-fluorescent components, including the polysaccharide-like and aliphatic compounds of DOM, that are involved in DOM-VA interactions $[29,31,81]$. The aromatic ring and double bond region were found to be the primary binding sites in DOM-VA interactions [31]. The FTIR spectra of HA-FQ interaction showed that $\mathrm{O}-\mathrm{H}, \mathrm{C}-\mathrm{H}$, and $-\mathrm{COOH}$ were important functional groups involved in the interactions, while N-H involvement was observed only for certain FQs [31]. Similarly, amide I and II, aromatics, and aliphatic were found to be the main functional groups of DOM responsible for the complexation of TCs in DOM-TC interactions [89]. Therefore, FTIR spectra can be used to reveal the extent of DOM-VA binding associated with DOM functional groups. In many studies (as shown in Table 2), various spectroscopic methods were used in combination to provide details of DOM-VA binding interactions at a molecular scale (e.g., [31,81,89]).

Nuclear magnetic resonance (NMR) spectroscopy is a simple, sensitive, and effective technique that can be used to monitor the molecular changes at the DOM-VA interaction sites [31,121]. For example, in the ${ }^{1} \mathrm{H}$ NMR spectra, gradually weakened and broadened proton signals of FQs with increasing HA concentration were observed; a chemical shift occurred mainly in the aromatic and double region $(\geq 6.9 \mathrm{ppm})$, while a diamagnetic shift was seen in the aliphatic regions (1-4.7 ppm), reflecting a strong interaction between HA and FQ [31]. Carboxyl and phenolic hydroxyl groups of $\mathrm{HA}$ and $-\mathrm{N}\left(\mathrm{CH}_{3}\right)_{2}$ groups of TCs were engaged in HA-tetracycline antibiotic interactions [121]. Therefore, NMR is useful and can provide rich structural information with a higher accuracy and sensitivity about DOM-VA interactions.

\subsubsection{High-Resolution Mass Spectrometry (HRMS) of DOM}

High-resolution mass spectrometry (HRMS) is a powerful tool that has been widely used to elucidate the DOM structural composition [103,131-133]. HRMS can provide a wide dynamic range of screening and reliable quantitative DOM molecular nature at a higher resolution. It can accurately identify, quantify, and determine the molecular composition of DOM $[103,131,134]$. Among the HRMS instruments, Fourier transform ion cyclotron resonance mass spectrometry (FTICR-MS) is widely used. In recent years, Orbitrap HRMS has become popular as a valid alternative to FTICR-MS. For instance, Orbitrap HRMS was found useful and was employed for identifying the potential DOM components associated with VAs in groundwater [103].

Integration of spectroscopic methods in studying DOM-VA interactions can provide an accurate understanding of the DOM molecular structures, functional groups, and predominant components involved in binding interactions with VAs, which could stimulate the development of novel techniques for the assessment of environmental risk and remediation of VA pollution. 


\subsection{Binding Stability of DOM-VA Interactions}

The binding stability of the DOM-VA interaction is a key factor affecting the transport behaviour of VAs in the presence of DOM. The Stern-Volmer equation is popularly used to fit the quenching data for quantitative description of DOM-VA interactions and to estimate parameters including the quenching rate constant [24]. Fluorescence decay curves plotted from the fluorescence intensity data can provide more valuable information on the quenching mechanism [31]. With the site-binding equation, the binding constant $\left(K_{\mathrm{b}}\right)$ and number of binding sites $(n)$ in DOM-VA interactions can be obtained [31,102,135]. In addition to the Stern-Volmer equation and site-binding equation, the magnitude and signs of thermodynamic functions (e.g., Van't Hoff equation) can be used to explore the major forces contributing to HA-quinolone antibiotic binding stability $[32,116]$.

It has been recognized that increasing the temperature may lead to a greater extent of collisional quenching, while decreasing the temperature may result in the formation of more non-fluorophore complexes $[29,136,137]$. In a study on interactions between FQs with DOM, the Stern-Volmer quenching constant and the binding constant was found to increase with the decreasing temperature, which indicates strong static quenching interactions between FQs and HA [31]; negative values of enthalpy $\left(\Delta H^{0}\right)$ and entropy $\left(\Delta S^{0}\right)$ were observed, which indicate a well-organised conformation of HA-quinolone antibiotic complexes involving van der Waals forces, hydrogen bonding, and electrostatic interaction; however, positive $\Delta G^{0}$ values were obtained, which indicate the binding processes were exothermic and not thermodynamically favourable [31]. In a study on the binding interactions of six FQs with HA over wide temperature ranges, it was found that all the FQs were quenched through a static mechanism, and the equilibrium binding constants were $<1\left(K_{\mathrm{b}}: 0.0332\right.$ to 0.172 at $\left.25{ }^{\circ} \mathrm{C}\right)$, indicating that most of the antibiotics remained unbound in the system; negative values of $\Delta H$ and $\Delta S$ were obtained, implying that hydrogen bonding was involved in HA-quinolone antibiotic interactions [116]. In a study on the binding characteristics of HA-quinolone antibiotic using the Ryan and Weber model, the stability constant $\left(K_{\mathrm{M}}\right)$ ranged from 0.86 to $4.07 \mathrm{~L} \mathrm{mg}^{-1}$ and higher $K_{\mathrm{M}}$ values were associated with a higher total ligand concentration of HA [114].

In particular, dynamic quenching was found to contribute significantly to the overall fluorescence quenching of ofloxacin by HA [29]. The formation of complexes by tyrosine and tryptophan with TCs (protein-like-TCs) was stronger than that of the complexes formed by humic-like substance, as indicated by the effective quenching constant values [89]. The binding stability of the DOM-VA interaction is a significant factor that may moderate the fate of VAs in the presence of DOM.

\section{Modelling the Transport of VAs under DOM Impact}

There are two categories of models that can be used to simulate the transport of antibiotics in soil as affected DOM. These models have been largely applied for homogeneous soils so far.

\subsection{Transport Models}

\subsubsection{Chemical Nonequilibrium Transport Models}

The chemical nonequilibrium models are built on the assumption that, in homogenous soils (such as repacked soil columns), chemical factors are responsible for the nonequilibrium transport behaviours of reactive solutes $[138,139]$. The simplest form of the chemical nonequilibrium transport model is an advection-dispersion equation coupled with one kinetic site sorption model. One kinetic site sorption model assumes that the sorption of reactive solute occurs kinetically in a uniform transport domain, and it is usually described using the first-order equation. Thus, the conventional advection-dispersion equation is modified to include a first-order equation that describes the one-site sorption model, as given below [92]:

$$
\frac{\partial n c}{\partial t}+\rho \frac{\partial S}{\partial t}=\frac{\partial}{\partial z}\left(\theta D \frac{\partial c}{\partial z}\right)-\frac{\partial q c}{\partial z}
$$




$$
\begin{gathered}
\rho \frac{\partial S}{\partial t}=\theta k_{\mathrm{att}} \psi c-k_{\mathrm{det}} \rho S \\
\psi=1-\frac{S}{S_{\max }}
\end{gathered}
$$

where $n$ is the porosity $\left(\mathrm{L}^{3} \mathrm{~L}^{-3}\right) ; t$ is time $(\mathrm{T}) ; c$ is the solution concentration $\left(\mathrm{M} \mathrm{L}^{-3}\right) ; S$ is the sorbed concentration on kinetic sorption sites $\left(\mathrm{M} \mathrm{M}^{-1}\right) ; \theta$ is the water content $\left(\mathrm{L}^{3} \mathrm{~L}^{-3}\right)$; $D$ is the hydrodynamic dispersion coefficient $\left(\mathrm{L}^{-2} \mathrm{~T}^{-1}\right) ; z$ is the coordinate parallel to flow (L); $\rho$ is the bulk density $\left(\mathrm{M} \mathrm{L}^{-3}\right) ; q$ is the flow rate $\left(\mathrm{L} \mathrm{T}^{-1}\right) ; k_{\text {att }}$ and $k_{\text {det }}$ are the first-order attachment rate and detachment rate, respectively $\left(\mathrm{L}^{-1}\right) ; \psi$ is a dimensionless function that describes the Langmuirian blocking; and $S_{\max }$ is the saturated sorption capacity $\left(\mathrm{M} \mathrm{M}^{-1}\right)$.

The one kinetic site sorption model can further be extended by conceptually dividing the sorption sites into two fractions. It is assumed that instantaneous sorption occurs on one fraction of the sites (Type 1 sites), while sorption on the other fraction (Type 2 sites) is kinetically controlled:

$$
S=S^{\mathrm{e}}+S^{\mathrm{k}}
$$

where $S^{\mathrm{e}}$ and $S^{\mathrm{k}}\left(\mathrm{M} \mathrm{M}^{-1}\right)$ are fractions of the sorption sites assumed to be instantaneous (Type 1) and first-order kinetic rate (Type 2), respectively.

Accordingly, the conventional advection-dispersion equation is modified to be the two sorption site model as follows:

$$
\begin{gathered}
\frac{\partial c}{\partial t}+\rho \frac{\partial S^{e}}{\partial t}+\rho \frac{\partial S^{\mathrm{k}}}{\partial t}=\frac{\partial}{\partial z}\left(\theta D \frac{\partial c}{\partial z}\right)-\frac{\partial q c}{\partial z}-\phi \\
S^{\mathrm{e}}=f_{\mathrm{e}} K_{\mathrm{d} c} \\
\rho \frac{\partial S^{\mathrm{k}}}{\partial t}=\alpha_{\mathrm{k}} \rho\left(S_{\mathrm{e}}^{\mathrm{k}}-S^{\mathrm{k}}\right)-\phi_{\mathrm{k}} \\
S_{\mathrm{e}}^{\mathrm{k}}=\left(1-f_{\mathrm{e}}\right) K_{\mathrm{d}} c
\end{gathered}
$$

where $f_{\mathrm{e}}$ is the fraction of sorption sites in equilibrium with liquid-phase (dimensionless), $K_{\mathrm{d}}$ is the linear sorption coefficient $\left(\mathrm{L}^{3} \mathrm{M}^{-1}\right), \alpha_{\mathrm{k}}$ is the first-order rate coefficient associated with the kinetic site $\left(\mathrm{T}^{-1}\right)$, and $\varphi$ is the sink term $\left(\mathrm{n} \mathrm{L}^{-3} \mathrm{~T}^{-1}\right)$.

The two sorption site model (Equation (5)) can be transformed into the two kinetic site model by the concept that sorption could occur kinetically on both fractions of the sorption sites and proceed at different rates (Equation (9)), which can be written as:

$$
\begin{gathered}
\frac{\partial c}{\partial t}+\rho \frac{\partial S_{1}^{\mathrm{k}}}{\partial t}+\rho \frac{\partial S_{2}^{\mathrm{k}}}{\partial t}=\frac{\partial}{\partial z}\left(\theta D \frac{\partial c}{\partial z}\right)-\frac{\partial q c}{\partial z}-\phi \\
\rho \frac{\partial S_{1}^{\mathrm{k}}}{\partial t}=k_{\mathrm{a} 1} \theta c-k_{\mathrm{d} 1} \rho S_{1}^{\mathrm{k}}-\phi_{\mathrm{k} 1} \\
\rho \frac{\partial S_{2}^{\mathrm{k}}}{\partial t}=k_{\mathrm{a} 2} \theta c-k_{\mathrm{d} 2} \rho S_{2}^{\mathrm{k}}-\phi_{\mathrm{k} 2}
\end{gathered}
$$

where $\partial S_{1}^{k}$ and $\partial S_{2}^{k}$ are the sorbed concentration of the first and second kinetic sorption sites, respectively $\left(\mathrm{M} \mathrm{M}^{-1}\right) ; k_{\mathrm{a} 1}$ and $k_{\mathrm{a} 2}$ are the attachment coefficients of the first and second fraction of kinetic sorption sites, respectively $\left(\mathrm{T}^{-1}\right) ; k_{\mathrm{d} 1}$ and $k_{\mathrm{d} 2}$ are the detachment coefficients of the first and second fraction of kinetic sorption sites, respectively $\left(\mathrm{T}^{-1}\right)$; and $\phi_{k 1}$ and $\phi_{k 2}$ are the sink term for the first and second kinetic sorption that represent various reactions at the kinetic sorption sites $\left(\mathrm{n} \mathrm{L}^{-3} \mathrm{~T}^{-1}\right)$ respectively.

In the same way, it can be reduced to one kinetic site sorption model when the kinetic sorption rates on both site fractions are the same, or can be reduced to a chemical equilibrium model when both rates are equally high to be considered instantaneous. These models have been successfully used to describe VA transport with the presence of DOM $[92,95,101,102]$. 


\subsubsection{Colloid-Facilitated Contaminant Transport Models}

Contaminant transport in soil occurs not only in dissolved form but also in association with moving colloids. This mechanism of contaminant migration has been reported for numerous contaminants in the literature, including heavy metals [22,140,141], pesticides [142,143], and pharmaceuticals $[33,144,145]$. Colloid-associated contaminants may migrate at a rate faster than the non-sorbing tracer [146], which contributes an essential pathway for rapid contaminant transport, especially for highly sorbing organic contaminants in natural soil and groundwater [22,34,147-149]. Therefore, any fate and transport model for strongly sorbing contaminants that does not account for colloid-facilitated transport may under predict their migration potentials [22,147].

As DOM colloids satisfy the prerequisite to facilitate the transport of VAs in subsurface soil [22,23,150], a few studies have modelled VA transport in association with DOM [33,34]. The conceptual models for the colloid-facilitated transport of contaminants in subsurface soil and their mathematical descriptions have been presented in previous studies $[22,23,150,151]$. These models were built on the existing classical advection-dispersion equation (ADE) for water and solute transport based on the Richards equation. Flury and Qiu [147] provided a comprehensive review of the colloids and colloid facilitated transport of contaminants in the vadose zone. Here, we give a brief description of the model components and a summary of recent applications for VA transport prediction.

The one-dimensional form of the mass balance equations for the total contaminant transport in association with colloids under variably-saturated conditions is given as [22,150]:

$$
\begin{aligned}
\frac{\partial \theta C}{\partial t}+ & \rho \frac{\partial S}{\partial t}+\frac{\partial A_{\mathrm{aw}} \Gamma}{\partial t}+\frac{\partial \theta_{\mathrm{w}} C_{\mathrm{c}} S_{\mathrm{mc}}}{\partial t}+\rho \frac{\partial S_{\mathrm{c}} S_{\mathrm{ic}}}{\partial t}+\frac{\partial A_{\mathrm{aw}} \Gamma_{\mathrm{c}} S_{\mathrm{mc}}}{\partial t} \\
& =\frac{\partial}{\partial z}\left(\theta D \frac{\partial C}{\partial z}\right)-\frac{\partial q C}{\partial z}+\frac{\partial}{\partial z}\left(\theta_{c} D_{c} \frac{\partial C_{\mathrm{c}} S_{\mathrm{mc}}}{\partial z}\right)-\frac{\partial q_{\mathrm{c}} C_{\mathrm{c}} S_{\mathrm{mc}}}{\partial z}+R
\end{aligned}
$$

where $C, S$, and $T$ are the concentration of contaminant in the liquid phase $\left(\mathrm{M} \mathrm{L}^{-3}\right)$, sorbed concentration on solid-phase $\left(\mathrm{M} \mathrm{M}^{-1}\right)$, and air-water interphase $\left(\mathrm{M} \mathrm{M}^{-2}\right)$, respectively; $S_{\mathrm{mc}}, S_{\mathrm{ic}}$, and $S_{\mathrm{ac}}$ are concentrations of contaminant sorbed to mobile colloids in liquidphase, immobile colloids on solid phase, and immobile colloids on the air-water interphase, respectively $\left(\mathrm{M} \mathrm{n}^{-1}\right) ; D$ and $q$ are the dispersion coefficient $\left(\mathrm{L}^{2} \mathrm{~T}^{-1}\right)$ and volumetric water flux $\left(\mathrm{L} \mathrm{T}^{-1}\right)$, respectively; and $R$ represents contaminant reactions and degradation in all phases $\left(\mathrm{M} \mathrm{L}^{-3} \mathrm{~T}^{-1}\right)$.

\subsection{Model Applications}

The presence of DOM can lead to changes in the number, nature, and reactivity of the sorption sites in the soil matrix domain, and thus complicate the transport of VAs in the soil. The chemical nonequilibrium models can be used to characterize both the transport behaviour and the sorption-desorption mechanism of antibiotics in homogeneous transport media through various conceptualisations, as described above (Equations (1)-(11); Table 3). For instance, in a column study, the competition of HA for available sorption sites on sand was evidenced in the transport of tetracycline, and the breakthrough curve (BTCs) of tetracycline can be satisfactorily described by the two sorption site model [101]. With increasing the HA concentration from 0 to $80 \mathrm{mg} \mathrm{L}^{-1}$, the fraction of equilibrium sorption site $\left(f_{\mathrm{e}}\right)$ decreased from 0.185 to 0.133 , while the kinetic rate constant $\left(\alpha_{\mathrm{k}}\right)$ increased from 1.91 to $3.72 \mathrm{~d}^{-1}$, which suggest a significant expansion of the nonequilibrium sorption sites $\left(1-f_{\mathrm{e}}\right)$ in the presence of DOM. Similarly, competitive sorption of DOM with various other antibiotics such as chlortetracycline, tylosin, sulfamethazine, and nalidixic acid was found to be responsible for the enhanced mobility of the antibiotics observed [92,95]. The fitting results of the antibiotic BTCs with the two sorption site model showed that, upon DOM addition, the mobility of chlortetracycline was greatly enhanced in both the surface and subsurface soils, while increased mobility of tylosin and sulfamethazine was observed only in surface soil columns, which had higher organic matter contents relative to the corresponding subsurface soil columns [95]. For nalidixic acid transport upon the addition of DOM, it was found that parameter $\alpha_{\mathrm{k}}$ increased from 0.00095 to $0.05800 \mathrm{~h}^{-1}$, 
and the fitted $K_{\mathrm{d}}$ reduced from 39.77 to $7.60 \mathrm{~cm}^{3} \mathrm{~g}^{-1}$, which revealed facilitated transport and nonlinear kinetic binding of nalidixic acid on the mineral surface [102]. In another study on tetracycline transport, one kinetic sorption site model was used, and decreases in the attachment rate $\left(k_{\mathrm{att}}\right)$ (from 1.135 to $0.665 \mathrm{~min}^{-1}$ ) and saturated sorption capacity $\left(S_{\max }\right)$ (from 2.990 to $2.617 \mathrm{mg} \mathrm{g}^{-1}$ ) but increases in the detachment rate ( $k_{\mathrm{det}}$ ) (from 0.001 to $0.010 \mathrm{~min}^{-1}$ ) were observed with the increasing HA concentration [92]. The colloid facilitated transport model could also be used to simulate the BTCs of SAs and manure $\mathrm{DOM}$, as indicated by the normalised root mean square error (NRMSE) ranging from 0.01 to 0.39 [33]. It was found that manure DOM facilitated transport of florfenicol in homogeneously packed soil columns could be successfully described by both the two sorption site model and the colloid-facilitated contaminant transport model, with the latter performing slightly better [34] (Table 3).

DOM derived from diverse sources may have different chemical properties, which complicate their interactions with Vas, as well as soil components. Accurate model simulation of VA transport in natural soils under the influences of DOM is essential for the assessment and control of VA pollution risk. So far, experimental and modelling studies on the effects of DOM-VA interactions on VA transport in soil have been mostly limited to a laboratory soil column scale. There is clearly a need for improved transport models applicable to heterogeneous complex field conditions and varying scenarios in farmland. 
Table 3. Applications of models in simulating the transport of VAs as affected by DOM.

\begin{tabular}{|c|c|c|c|c|c|c|c|c|c|c|c|}
\hline \multirow[t]{3}{*}{ Transport Species } & \multicolumn{4}{|c|}{ Injection Concentrations and Transport Conditions } & \multirow{2}{*}{\multicolumn{6}{|c|}{$\begin{array}{c}\text { Transport Model and Parameters } \\
\text { Colloid Facilitated Transport Model }\end{array}$}} & Reference \\
\hline & \multirow[b]{2}{*}{ DOM } & \multirow[b]{2}{*}{ VA } & \multirow[b]{2}{*}{ Media } & \multirow{2}{*}{$\begin{array}{l}\text { DOM Injection } \\
\text { Method }\end{array}$} & & & & & & & \\
\hline & & & & & $\begin{array}{l}k_{\mathrm{dec}} \\
\left(\mathrm{s}^{-1}\right)\end{array}$ & $\begin{array}{c}k_{a}^{m} \\
\left(\mathbf{L} \mathbf{~ m o l}^{-1} \mathbf{s}^{-1}\right)\end{array}$ & $\begin{array}{c}k_{d}^{m} \\
\left(\mathbf{s}^{-1}\right)\end{array}$ & $\begin{array}{c}k_{a}^{i m} \\
\left(\mathbf{L ~} \mathbf{~ m o l}^{-\mathbf{1}} \mathbf{s}^{-\mathbf{1}}\right)\end{array}$ & $\begin{array}{l}k_{d}^{i m} \\
\left(\mathbf{s}^{-1}\right)\end{array}$ & NRMSE & \\
\hline $\begin{array}{l}\text { Pig manure DOM and } \\
\text { sulfamethoxypyri- } \\
\text { dazine }\end{array}$ & $8-115 \mathrm{mg} \mathrm{L}^{-1}$ & $250 \mu \mathrm{g} \mathrm{L}{ }^{-1}$ & $\begin{array}{l}\text { Loamy sand } \\
\text { soil }\end{array}$ & Co-transport & $\begin{aligned} 1.98 & \times 10^{-9}-1.78 \\
& \times 10^{-5}\end{aligned}$ & $\begin{array}{l}4.14 \times 10^{-4}- \\
1.33 \times 10^{-2}\end{array}$ & $\begin{array}{l}1.49 \times 10^{-5} \\
5.14 \times 10^{-4}\end{array}$ & $\begin{array}{l}1.38 \times 10^{-3}- \\
5.23 \times 10^{-3}\end{array}$ & $\begin{array}{l}1.56 \times 10^{-7}- \\
6.62 \times 10^{-6}\end{array}$ & $0.01-0.09$ & \\
\hline \multirow[t]{3}{*}{$\begin{array}{l}\text { Pig manure DOM and } \\
\text { sulfamoxole }\end{array}$} & & & & & & $\begin{array}{l}1.93 \times 10^{-4}- \\
2.82 \times 10^{-1}\end{array}$ & $\begin{array}{l}2.01 \times 10^{-7}- \\
7.18 \times 10^{-4}\end{array}$ & $\begin{array}{l}3.00 \times 10^{-6} \\
7.14 \times 10^{-1}\end{array}$ & $\begin{array}{l}1.99 \times 10^{-3}- \\
1.56 \times 10^{-6}\end{array}$ & $0.02-0.23$ & \\
\hline & & & & & \multicolumn{6}{|c|}{ Advection dispersion equation coupled with two-site nonequilibrium sorption model } & \\
\hline & & & & & $K_{\mathrm{d}}\left(K_{\mathrm{f}} *\right)$ & $\begin{array}{c}\beta \\
(-)\end{array}$ & $\begin{array}{c}f_{\mathrm{e}} \\
(-)\end{array}$ & $\alpha_{\mathrm{k}}$ & $D$ & $\mathrm{R}^{2}$ & \\
\hline $\begin{array}{l}\text { Leonardite humic } \\
\text { acid (HA) and } \\
\text { nalidixic acid }\end{array}$ & $5-50 \mathrm{mg} \mathrm{L}^{-1}$ & $10 \mu \mathrm{M}$ & $\begin{array}{l}\text { Goethite- } \\
\text { coated } \\
\text { sand }\end{array}$ & $\begin{array}{l}\text { Pre-sorbed and } \\
\text { co-transport }\end{array}$ & $\begin{array}{l}3.72-34.55 \text { * } \\
\mathrm{cm}^{3} \mathrm{~g}^{-1}\end{array}$ & $0.74-1.15$ & 0.6 & $\begin{array}{c}0.00766-0.01859 \\
\mathrm{~h}^{-1}\end{array}$ & - & $0.989-0.999$ & [102] \\
\hline $\begin{array}{l}\text { Diluted dairy manure } \\
\text { DOM and florfenicol }\end{array}$ & $85 \mathrm{mg} \mathrm{L}^{-1}$ & $100 \mu \mathrm{g} \mathrm{mL}^{-1}$ & Silt loam & Co-transport & $\begin{array}{l}0.84 * \mathrm{~cm}^{3} \mathrm{~g}^{-1} \\
0.45 \mathrm{~cm}^{3} \mathrm{~g}^{-1}\end{array}$ & $\begin{array}{c}0.75 \\
-\end{array}$ & $0.61-0.51$ & $0.13-0.19 \mathrm{~h}^{-1}$ & $0.31 \mathrm{~cm}^{2} \mathrm{~h}^{-1}$ & $0.984-0.992$ & [34] \\
\hline $\begin{array}{l}\text { Dairy manure DOM } \\
\text { and chlortetracycline }\end{array}$ & \multirow{3}{*}{$21-63 \mathrm{mg} \mathrm{L}^{-1}$} & \multirow{3}{*}{$\begin{array}{c}0.07-0.58 \times \\
10^{-3} \mathrm{M}\end{array}$} & \multirow{3}{*}{$\begin{array}{l}\text { Sandy loam } \\
\text { soil }\end{array}$} & \multirow{3}{*}{ Co-transport } & $158-159 \mathrm{~L} \mathrm{~kg}^{-1}$ & - & $0.018-0.053$ & $0.027-0.085 \mathrm{~h}^{-1}$ & $\begin{array}{l}9.14-26.30 \\
\mathrm{~cm}^{2} \mathrm{~h}^{-1}\end{array}$ & $0.91-0.92$ & \multirow{3}{*}{ [95] } \\
\hline $\begin{array}{l}\text { Dairy manure DOM } \\
\text { and tylosin }\end{array}$ & & & & & $4.04-8.19 \mathrm{~L} \mathrm{~kg}^{-1}$ & - & $0.14-0.32$ & $0.10-0.29 \mathrm{~h}^{-1}$ & $\begin{array}{l}7.76-69.70 \\
\mathrm{~cm}^{2} \mathrm{~h}^{-1}\end{array}$ & $0.89-0.91$ & \\
\hline $\begin{array}{l}\text { Dairy manure DOM } \\
\text { and sulfamethazine }\end{array}$ & & & & & $0.30-0.45 \mathrm{~L} \mathrm{~kg}^{-1}$ & - & $0.21-0.56$ & $0.071-0.68 \mathrm{~h}^{-1}$ & $\begin{array}{l}5.19-30.40 \\
\mathrm{~cm}^{2} \mathrm{~h}^{-1}\end{array}$ & 0.99 & \\
\hline \multirow{2}{*}{$\begin{array}{l}\text { Soil HA and } \\
\text { tetracycline } \\
\text { Soil HA and pyrene }\end{array}$} & \multirow[t]{2}{*}{$20-80 \mathrm{mg} \mathrm{L}^{-1}$} & \multirow[t]{2}{*}{$10 \mathrm{mg} \mathrm{L}^{-1}$} & \multirow{2}{*}{$\begin{array}{l}\text { Fine-to- } \\
\text { medium-grain } \\
\text { sand }\end{array}$} & \multirow[t]{2}{*}{ Co-transport } & $\begin{array}{c}7.29-11.80 \mathrm{~L} \\
\mathrm{~kg}^{-1}\end{array}$ & $0.156-0.235$ & $0.133-0.214$ & $2.22-3.89 \mathrm{~d}^{-1}$ & $0.483 \mathrm{~cm}^{2} \mathrm{~d}^{-1}$ & 0.998 & \multirow{2}{*}[101]{} \\
\hline & & & & & $3.13-6.43 \mathrm{~L} \mathrm{~kg}^{-1}$ & $0.462-0.566$ & $0.432-0.553$ & $3.29-5.09 \mathrm{~d}^{-1}$ & $0.515 \mathrm{~cm}^{2} \mathrm{~d}^{-1}$ & 0.998 & \\
\hline
\end{tabular}


Table 3. Cont.

Transport Species Injection Concentrations and Transport Conditions

Transport Model and Parameters

Reference

Advection dispersion equation coupled with two kinetic site model

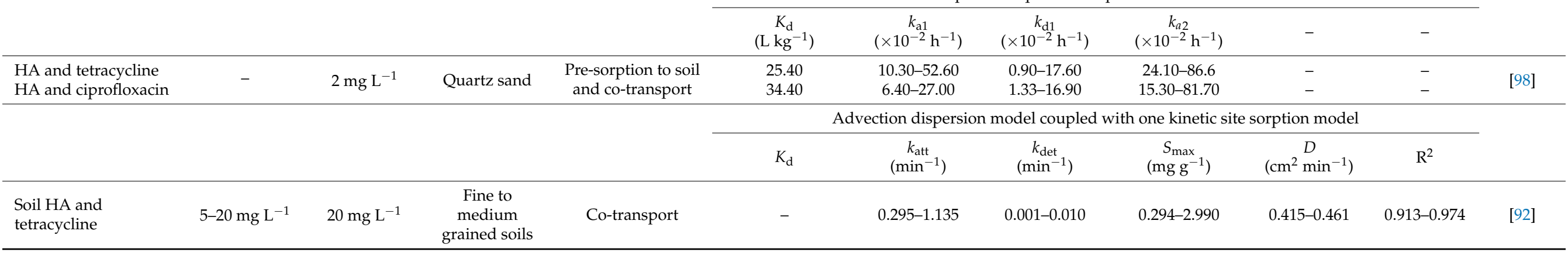

Notes: $k_{\mathrm{dec}}$ is the colloid decay rate constant; $k_{a}^{m}$ and $k_{d}^{m}$ are the attachment and detachment rate coefficients for the mobile colloids, respectively; $k_{a}^{i m}$ and $k_{d}^{i m}$ are the attachment and detachment rate coefficients for the immobile colloids, respectively. $K_{\mathrm{d}}$ is the linear sorption coefficient; $K_{\mathrm{f}}$ is the Freundlich isotherm sorption coefficient; $\beta$ is an empirical parameter that characterises the degree of nonlinearity; $f_{e}$ is the fraction of instantaneous equilibrium sorption (Type-1) sites; $\alpha_{\mathrm{k}}$ is the first-order rate coefficient associated with the kinetic site; $D$ is the dispersion coefficient. $k_{\mathrm{a} 1}$ and $k_{\mathrm{a} 2}$ are the first order attachment rate of Type 1 site and Type 2 site, respectively; $k_{\mathrm{d} 1}$ is the first-order detachment rate of Type 1 site. $k_{\mathrm{att}}$ and $k_{\mathrm{det}}$ are the first-order attachment rate and detachment rate, respectively; $S_{\max }$ is the saturated sorption capacity. The number followed by * represents the value of $K_{\mathrm{f}}$. 


\section{Conclusions and Future Research}

Veterinary antibiotic contamination in farmland has attracted global attention due to the potential risks to the agroecosystem and the consequential impacts on human health. Even though some studies have investigated the transport of VAs, the unavoidable DOM-VA interactions made the investigation of VA transport in the presence of DOM a complex one. DOM can alter the sorption-desorption and leaching behaviour of VAs in farmland soil due to its high reactivity and mobility nature. The consequences of DOM-VA interactions on the environmental fate and risk of VAs have two facets. First, DOM-VA binding interactions can increase the persistence of VAs in soil through complexation and cosorption on the soil matrix. This could increase the potential risk of antibiotic contamination to human health and may induce the development of ARGs in the environment. Second, DOM-VA interactions can enhance the leaching and transport of some VAs via competitive sorption that promotes VA desorption from soils or through the facilitated transport of VAs attached to mobile DOM. Adequate knowledge about the fate and transport of VAs under the influence of DOM derived from various soil amendments and organic fertilisers of diverse origins is crucial for the VA pollution risk assessment. Moreover, some measures, such as pre-treating manure to reduce antibiotic content by composting or anaerobic digestion, adding to manure or soil some sorbents or specific microorganisms, which can degrade VAs, could be considered as potential solutions to the antibiotic pollution problem in manured farmland.

Spectroscopic investigation of DOM-VA interactions can provide molecular evidence for understanding the mobility of VAs in soil. Nevertheless, effects of DOM-VA interactions on the transport of VAs under field conditions are still poorly understood. Therefore, we recommend the incorporation of DOM-VA interaction studies into simulation of VA transport. In addition, the significant variability in chemical properties of DOM derived from diverse sources and their potential to alter the fate of VAs in soil need to be investigated in the future. It is essential to consider undisturbed soil columns and lysimeters instead of repacked ones and to develop better transport models applicable to varying DOM-VA interaction scenarios in the field, where macropore preferential flow may prevail.

Supplementary Materials: The following are available online at https:/ /www.mdpi.com/article/10 .3390/ijerph19031702/s1, Table S1. Nature and parameters of DOM from various sources.

Author Contributions: Conceptualisation, L.A.G., X.T., C.L.; writing-original draft preparation, L.A.G.; writing-review and editing, L.A.G., X.T., C.L. and J.C.; supervision, X.T. and C.L. All authors have read and agreed to the published version of the manuscript.

Funding: This study was supported by the National Natural Science Foundation of China (Grant Nos. 41771521 and 41790431) and the Youth Innovation Promotion Association, Chinese Academy of Sciences. L.A.G. appreciates the support from CAS-TWAS President's Fellowship for international PhD students.

Institutional Review Board Statement: Not applicable.

Informed Consent Statement: Not applicable.

Data Availability Statement: Not applicable.

Conflicts of Interest: The authors declare no conflict of interest.

\section{References}

1. Van Boeckel, T.P.; Brower, C.; Gilbert, M.; Grenfell, B.T.; Levin, S.A.; Robinson, T.P.; Teillant, A.; Laxminarayan, R. Global trends in antimicrobial use in food animals. Proc. Natl. Acad. Sci. USA 2015, 112, 5649-5694. [CrossRef] [PubMed]

2. Kumar, K.; Gupta, S.C.; Chander, Y.; Singh, A.K. Antibiotic use in agriculture and its impact on the terrestrial environment. Adv. Agron. 2005, 87, 1-54.

3. Sarmah, A.K.; Meyer, M.T.; Boxall, A.B.A. A global perspective on the use, sales, exposure pathways, occurrence, fate and effects of veterinary antibiotics (VAs) in the environment. Chemosphere 2006, 65, 725-759. [CrossRef] [PubMed] 
4. Zhang, Q.Q.; Ying, G.G.; Pan, C.G.; Liu, Y.S.; Zhao, J.L. Comprehensive evaluation of antibiotics emission and fate in the river basins of China: Source analysis, multimedia modeling, and linkage to bacterial resistance. Environ. Sci. Technol. 2015, 49, 6772-6782. [CrossRef]

5. Chen, Y.S.; Zhang, H.B.; Luo, Y.M.; Song, J. Occurrence and assessment of veterinary antibiotics in swine manures: A case study in East China. Chin. Sci. Bull. 2012, 57, 606-614. [CrossRef]

6. Song, W.; Guo, M. Residual Veterinary Pharmaceuticals in Animal Manures and Their Environmental Behaviors in Soils. In Applied Manure and Nutrient Chemistry for Sustainable Agriculture and Environment; He, Z., Zhang, H., Eds.; Springer: Dordrecht, The Netherlands, 2014; pp. 23-52.

7. Chen, K.L.; Liu, L.C.; Chen, W.R. Adsorption of sulfamethoxazole and sulfapyridine antibiotics in high organic content soils. Environ. Pollut. 2017, 231, 1163-1171. [CrossRef]

8. Ding, G.C.; Radl, V.; Schloter-Hai, B.; Jechalke, S.; Heuer, H.; Smalla, K.; Schloter, M. Dynamics of soil bacterial communities in response to repeated application of manure containing sulfadiazine. PLoS ONE 2014, 9, e92958.

9. Tien, Y.-C.; Li, B.; Zhang, T.; Scott, A.; Murray, R.; Sabourin, L.; Marti, R.; Topp, E. Impact of dairy manure pre-application treatment on manure composition, soil dynamics of antibiotic resistance genes, and abundance of antibiotic-resistance genes on vegetables at harvest. Sci. Total Environ. 2017, 581-582, 32-39. [CrossRef]

10. Ding, H.J.; Wu, Y.X.; Zhang, W.H.; Zhong, J.Y.; Lou, Q.; Yang, P.; Fang, Y.Y. Occurrence, distribution, and risk assessment of antibiotics in the surface water of Poyang Lake, the largest freshwater lake in China. Chemosphere 2017, 184, 137-147. [CrossRef]

11. Peng, S.; Feng, Y.; Wang, Y.; Guo, X.; Chu, H.; Lin, X. Prevalence of antibiotic resistance genes in soils after continually applied with different manure for 30 years. J. Hazard. Mater. 2017, 340, 16-25. [CrossRef]

12. Zhu, B.K.; Chen, Q.L.; Chen, S.C.; Zhu, Y.G. Does organically produced lettuce harbor higher abundance of antibiotic resistance genes than conventionally produced? Environ. Int. 2017, 98, 152-159. [CrossRef] [PubMed]

13. Kovalakova, P.; Cizmas, L.; McDonald, T.J.; Marsalek, B.; Feng, M.; Sharma, V.K. Occurrence and toxicity of antibiotics in the aquatic environment: A review. Chemosphere 2020, 251, 126351. [CrossRef]

14. Bair, D.A.; Popova, I.E.; Tate, K.W.; Parikh, S.J. Transport of oxytetracycline, chlortetracycline, and ivermectin in surface runoff from irrigated pasture. J. Environ. Sci. Health Part B 2017, 52, 631-640. [CrossRef] [PubMed]

15. Engelhardt, I.; Sittig, S.; Šimůnek, J.; Groeneweg, J.; Pütz, T.; Vereecken, H. Fate of the antibiotic sulfadiazine in natural soils: Experimental and numerical investigations. J. Contam. Hydrol. 2015, 177-178, 30-42. [CrossRef] [PubMed]

16. Kay, P.; Blackwell, P.A.; Boxall, A.B.A. Column studies to investigate the fate of veterinary antibiotics in clay soils following slurry application to agricultural land. Chemosphere 2005, 60, 497-507. [CrossRef] [PubMed]

17. Pan, M.; Chu, L.M. Leaching behavior of veterinary antibiotics in animal manure-applied soils. Sci. Total Environ. 2017, 579, 466-473. [CrossRef]

18. Vasudevan, D.; Bruland, G.L.; Torrance, B.S.; Upchurch, V.G.; MacKay, A.A. pH-dependent ciprofloxacin sorption to soils: Interaction mechanisms and soil factors influencing sorption. Geoderma 2009, 151, 68-76. [CrossRef]

19. Kay, P.; Blackwell, P.A.; Boxall, A.B.A. Fate of veterinary antibiotics in a macroporous tile drained clay soil. Environ. Toxicol. Chem. 2004, 23, 1136-1144. [CrossRef]

20. Lei, W.; Tang, X.; Zhou, X. Transport of 3,5,6-trichloro-2-pyrdionl (a main pesticide degradation product) in purple soil: Experimental and modeling. Appl. Geochem. 2018, 88, 179-187. [CrossRef]

21. Xing, Y.; Chen, X.; Zhuang, J.; Chen, X. What happens when pharmaceuticals meet colloids. Ecotoxicology 2015, 24, $2100-2114$. [CrossRef]

22. Šimůnek, J.; He, C.; Pang, L.; Bradford, S.A. Colloid-facilitated solute transport in variably saturated porous media: Numerical model and experimental verification. Vadose Zone J. 2006, 5, 1035-1047. [CrossRef]

23. Bradford, S.A.; Šimůnek, J.; Bettahar, M.; van Genuchten, M.T.; Yates, S.R. Modeling colloid attachment, straining, and exclusion in saturated porous media. Environ. Sci. Technol. 2003, 37, 2242-2250. [CrossRef] [PubMed]

24. Bai, L.; Cao, C.; Wang, C.; Wang, C.; Zhang, H.; Jiang, H. Roles of phytoplankton- and macrophyte-derived dissolved organic matter in sulfamethazine adsorption on goethite. Environ. Pollut. 2017, 230, 87-95. [CrossRef] [PubMed]

25. Haham, H.; Oren, A.; Chefetz, B. Insight into the role of dissolved organic matter in sorption of sulfapyridine by semiarid soils. Environ. Sci. Technol. 2012, 46, 11870-11877. [CrossRef] [PubMed]

26. Lei, K.; Han, X.; Fu, G.; Zhao, J.; Yang, L. Mechanism of ofloxacin fluorescence quenching and its interaction with sequentially extracted dissolved organic matter from lake sediment of Dianchi, China. Environ. Monit. Assess. 2014, 186, 8857-8864. [CrossRef] [PubMed]

27. Lou, Y.Y.; Ye, Z.L.; Chen, S.H.; Wei, Q.S.; Zhang, J.Q.; Ye, X. Influences of dissolved organic matters on tetracyclines transport in the process of struvite recovery from swine wastewater. Water Res. 2018, 134, 311-326. [CrossRef]

28. Tolls, J. Sorption of veterinary pharmaceuticals in soils: A Review. Environ. Sci. Technol. 2001, 35, 3397-3406. [CrossRef]

29. Wang, L.; Liang, N.; Li, H.; Yang, Y.; Zhang, D.; Liao, S.; Pan, B. Quantifying the dynamic fluorescence quenching of phenanthrene and ofloxacin by dissolved humic acids. Environ. Pollut. 2015, 196, 379-385. [CrossRef]

30. Zhao, Y.; Gu, X.; Gao, S.; Geng, J.; Wang, X. Adsorption of tetracycline (TC) onto montmorillonite: Cations and humic acid effects. Geoderma 2012, 183-184, 12-18. [CrossRef]

31. Zhao, X.; Hu, Z.; Yang, X.; Cai, X.; Wang, Z.; Xie, X. Noncovalent interactions between fluoroquinolone antibiotics with dissolved organic matter: A ${ }^{1}$ H NMR binding site study and multi-spectroscopic methods. Environ. Pollut. 2019, 248, 815-822. [CrossRef] 
32. Xu, J.; Yu, H.Q.; Sheng, G.P. Kinetics and thermodynamics of interaction between sulfonamide antibiotics and humic acids: Surface plasmon resonance and isothermal titration microcalorimetry analysis. J. Hazard. Mater. 2016, 302, 262-266. [CrossRef] [PubMed]

33. Zhou, D.; Thiele-Bruhn, S.; Arenz-Leufen, M.G.; Jacques, D.; Lichtner, P.; Engelhardt, I. Impact of manure-related DOM on sulfonamide transport in arable soils. J. Contam. Hydrol. 2016, 192, 118-128. [CrossRef] [PubMed]

34. Zou, Y.; Zheng, W. Modeling manure colloid-facilitated transport of the weakly hydrophobic antibiotic florfenicol in saturated soil columns. Environ. Sci. Technol. 2013, 47, 5185-5192. [CrossRef] [PubMed]

35. Gao, S.J.; Zhao, C.; Shi, Z.H.; Zhong, J.; Liu, J.G.; Li, J.Q. Spectroscopic characteristics of dissolved organic matter in afforestation forest soil of Miyun district, Beijing. J. Anal. Methods Chem. 2016, 2016, 1480857. [CrossRef]

36. Qu, X.; Xie, L.; Lin, Y.; Bai, Y.; Zhu, Y.; Xie, F.; Giesy, J.P.; Wu, F. Quantitative and qualitative characteristics of dissolved organic matter from eight dominant aquatic macrophytes in Lake Dianchi, China. Environ. Sci. Pollut. Res. 2013, 20, 7413-7423. [CrossRef]

37. Rajapaksha, A.U.; Ok, Y.S.; El-Naggar, A.; Kim, H.; Song, F.; Kang, S.; Tsang, Y.F. Dissolved organic matter characterization of biochars produced from different feedstock materials. J. Environ. Manag. 2019, 233, 393-399. [CrossRef]

38. Lankes, U.; Lüdemann, H.-D.; Frimmel, F.H. Search for basic relationships between "molecular size" and "chemical structure" of aquatic natural organic matter-Answers from ${ }^{13} \mathrm{C}$ and ${ }^{15}$ N CPMAS NMR spectroscopy. Water Res. 2008, 42, 1051-1060. [CrossRef]

39. Cuss, C.W.; Guéguen, C. Relationships between molecular weight and fluorescence properties for size-fractionated dissolved organic matter from fresh and aged sources. Water Res. 2015, 68, 487-497. [CrossRef]

40. Ghani, A.; Müller, K.; Dodd, M.; Mackay, A. Dissolved organic matter leaching in some contrasting New Zealand pasture soils. Eur. J. Soil Sci. 2010, 61, 525-538. [CrossRef]

41. Jansen, B.; Kalbitz, K.; McDowell, W.H. Dissolved organic matter: Linking soils and aquatic systems. Vadose Zone J. 2014, 13, vzj2014.05.0051. [CrossRef]

42. Li, X.M.; Chen, Q.L.; He, C.; Shi, Q.; Chen, S.C.; Reid, B.J.; Zhu, Y.G.; Sun, G.X. Organic carbon amendments affect the chemodiversity of soil dissolved organic matter and its associations with soil microbial communities. Environ. Sci. Technol. 2019, 53, 50-59. [CrossRef] [PubMed]

43. Briones, R.M.; Sarmah, A.K. Sorption and mobility of metformin and guanylurea in soils as affected by biosolid amendment: Batch and column tests. Environ. Pollut. 2019, 244, 19-27. [CrossRef] [PubMed]

44. Jamieson, T.; Sager, E.; Guéguen, C. Characterization of biochar-derived dissolved organic matter using UV-visible absorption and excitation-emission fluorescence spectroscopies. Chemosphere 2014, 103, 197-204. [CrossRef]

45. An, J.; Chen, H.; Wei, S.; Gu, J. Antibiotic contamination in animal manure, soil, and sewage sludge in Shenyang, northeast China. Environ. Earth. Sci. 2015, 74, 5077-5086. [CrossRef]

46. Zhang, H.; Schroder, J. Animal Manure Production and Utilization in the US. In Applied Manure and Nutrient Chemistry for Sustainable Agriculture and Environment; He, Z., Zhang, H., Eds.; Springer: Dordrecht, The Netherlands, $2014 ;$ pp. 1-21.

47. Tang, X.; Liu, C.; Luo, F.; Li, S.; Yang, H. Effects of colloidal manure DOM on the transport of antibiotics in calcareous soils. In Proceedings of the EGU General Assembly, Online, 19-30 April 2021; p. EGU21-9781.

48. Jia, M.; Wang, F.; Bian, Y.; Stedtfeld, R.D.; Liu, G.; Yu, J.; Jiang, X. Sorption of sulfamethazine to biochars as affected by dissolved organic matters of different origin. Bioresour. Technol. 2018, 248, 36-43. [CrossRef] [PubMed]

49. Sparling, G.P.; Chibnall, E.J.; Pronger, J.; Rutledge, S.; Wall, A.M.; Campbell, D.I.; Schipper, L.A. Estimates of annual leaching losses of dissolved organic carbon from pastures on Allophanic Soils grazed by dairy cattle, Waikato, New Zealand. N. Z. J. Agr. Res. 2016, 59, 32-49. [CrossRef]

50. Schneider, M.P.W.; Scheel, T.; Mikutta, R.; van Hees, P.; Kaiser, K.; Kalbitz, K. Sorptive stabilization of organic matter by amorphous Al hydroxide. Geochim. Cosmochim. Acta 2010, 74, 1606-1619. [CrossRef]

51. Saidy, A.R.; Smernik, R.J.; Baldock, J.A.; Kaiser, K.; Sanderman, J. The sorption of organic carbon onto differing clay minerals in the presence and absence of hydrous iron oxide. Geoderma 2013, 209-210, 15-21. [CrossRef]

52. Saidy, A.R.; Smernik, R.J.; Baldock, J.A.; Kaiser, K.; Sanderman, J. Microbial degradation of organic carbon sorbed to phyllosilicate clays with and without hydrous iron oxide coating. Eur. J. Soil Sci. 2015, 66, 83-94. [CrossRef]

53. Jiang, T.; Kaal, J.; Liang, J.; Zhang, Y.; Wei, S.; Wang, D.; Green, N.W. Composition of dissolved organic matter (DOM) from periodically submerged soils in the Three Gorges Reservoir areas as determined by elemental and optical analysis, infrared spectroscopy, pyrolysis-GC-MS and thermally assisted hydrolysis and methylation. Sci. Total Environ. 2017, 603-604, 461-471. [CrossRef]

54. Li, S.; Li, M.; Wang, G.; Sun, X.; Xi, B.; Hu, Z. Compositional and chemical characteristics of dissolved organic matter in various types of cropped and natural Chinese soils. Chem. Biol. Technol. Agric. 2019, 6, 20. [CrossRef]

55. Barker, J.D.; Dubnick, A.; Lyons, W.B.; Chin, Y.P. Changes in dissolved organic matter (DOM) fluorescence in Proglacial Antarctic streams. Arct. Antarct. Alp. Res. 2013, 45, 305-317. [CrossRef]

56. Gao, J.; Liang, C.; Shen, G.; Lv, J.; Wu, H. Spectral characteristics of dissolved organic matter in various agricultural soils throughout China. Chemosphere 2017, 176, 108-116. [CrossRef] [PubMed]

57. Gao, J.; Lv, J.; Wu, H.; Dai, Y.; Nasir, M. Impacts of wheat straw addition on dissolved organic matter characteristics in cadmiumcontaminated soils: Insights from fluorescence spectroscopy and environmental implications. Chemosphere 2018, 193, 1027-1035. [CrossRef] 
58. Zhang, X.; Ge, J.; Zhang, S.; Zhao, Y.; Cui, H.; Wei, Z.; Luo, S.; Cao, J. Bioavailability evaluation of dissolved organic matter derived from compost-amended soils. J. Agr. Food Chem. 2019, 67, 5940-5948. [CrossRef]

59. Wang, B.; Zeng, D.; Chen, Y.; Belzile, N.; Bai, Y.; Zhu, J.; Shu, J.; Chen, S. Adsorption behaviors of phenanthrene and bisphenol A in purple paddy soils amended with straw-derived DOM in the West Sichuan Plain of China. Ecotox. Environ. Saf. 2019, 169, 737-746. [CrossRef]

60. Su, L.; Chen, M.; Wang, S.; Ji, R.; Liu, C.; Lu, X.; Zhen, G.; Zhang, L. Fluorescence characteristics of dissolved organic matter during anaerobic digestion of oil crop straw inoculated with rumen liquid. RSC Adv. 2021, 11, 14347-14356. [CrossRef]

61. Wu, H.; Kida, M.; Domoto, A.; Hara, M.; Ashida, H.; Suzuki, T.; Fujitake, N. The effects of fertilization treatments and cropping systems on long-term dynamics and spectroscopic characteristics of dissolved organic matter in paddy soil. Soil Sci. Plant Nutr. 2019, 65, 557-565. [CrossRef]

62. Wang, B.; Li, M.; Zhang, H.; Zhu, J.; Chen, S.; Ren, D. Effect of straw-derived dissolved organic matter on the adsorption of sulfamethoxazole to purple paddy soils. Ecotox. Environ. Saf. 2020, 203, 110990. [CrossRef]

63. Li, X.; Shi, Z.; Wang, J.; Jiang, R. The quality of dissolved organic matter extracted at different times from pig compost and its copper binding capacity based on EEM-PARAFAC. Ecotox. Environ. Saf. 2021, 207, 111545. [CrossRef]

64. Huang, J.Y.; Yu, Z.X.; Gao, H.J.; Yan, X.M.; Chang, J.; Wang, C.M.; Hu, J.W.; Zhang, L.G. Chemical structures and characteristics of animal manures and composts during composting and assessment of maturity indices. PLoS ONE 2017, 12, e0178110. [CrossRef] [PubMed]

65. Kim, S.C.; Yang, J.E.; Ok, Y.S.; Carlson, K. Dissolved and colloidal fraction transport of antibiotics in soil under biotic and abiotic conditions. Water Qual. Res. J. Can. 2010, 45, 275-285. [CrossRef]

66. Xian, Q.; Li, P.; Liu, C.; Cui, J.; Guan, Z.; Tang, X. Concentration and spectroscopic characteristics of DOM in surface runoff and fracture flow in a cropland plot of a loamy soil. Sci. Total Environ. 2018, 622-623, 385-393. [CrossRef]

67. Veum, K.S.; Goyne, K.W.; Motavalli, P.P.; Udawatta, R.P. Runoff and dissolved organic carbon loss from a paired-watershed study of three adjacent agricultural Watersheds. Agr. Ecosyst. Environ. 2009, 130, 115-122. [CrossRef]

68. Ussiri, D.A.N.; Johnson, C.E. Sorption of organic carbon fractions by spodosol mineral horizons. Soil Sci. Soc. Am. J. 2004, 68, 253-262. [CrossRef]

69. Kahle, M.; Kleber, M.; Jahn, R. Retention of dissolved organic matter by phyllosilicate and soil clay fractions in relation to mineral properties. Org. Geochem. 2004, 35, 269-276. [CrossRef]

70. Feng, X.; Simpson, A.J.; Simpson, M.J. Chemical and mineralogical controls on humic acid sorption to clay mineral surfaces. Org. Geochem. 2005, 36, 1553-1566. [CrossRef]

71. Singh, M.; Sarkar, B.; Biswas, B.; Churchman, J.; Bolan, N.S. Adsorption-desorption behavior of dissolved organic carbon by soil clay fractions of varying mineralogy. Geoderma 2016, 280, 47-56. [CrossRef]

72. Wang, K.; Xing, B. Structural and sorption characteristics of adsorbed humic acid on clay minerals. J. Environ. Qual. 2005, 34, 342-349. [CrossRef]

73. Pils, J.R.V.; Laird, D.A. Sorption of tetracycline and chlortetracycline on K- and Ca-saturated soil clays, humic substances, and clay-humic complexes. Environ. Sci. Technol. 2007, 41, 1928-1933. [CrossRef]

74. Zhang, J.Q.; Dong, Y.H. Effect of low-molecular-weight organic acids on the adsorption of norfloxacin in typical variable charge soils of China. J. Hazard. Mater. 2008, 151, 833-839. [CrossRef] [PubMed]

75. Zhang, W.; Tang, X.; Thiele-Bruhn, S. Interaction of pig manure-derived dissolved organic matter with soil affects sorption of sulfadiazine, caffeine and atenolol pharmaceuticals. Environ. Geochem. Health 2021, 43, 4299-4313. [CrossRef] [PubMed]

76. Lian, F.; Sun, B.; Chen, X.; Zhu, L.; Liu, Z.; Xing, B. Effect of humic acid (HA) on sulfonamide sorption by biochars. Environ. Pollut. 2015, 204, 306-312. [CrossRef]

77. Ahmed, M.H.; Geleta, K.M.; Tazeze, A.; Mesfin, H.M.; Tilahun, E.A. Cropping systems diversification, improved seed, manure and inorganic fertilizer adoption by maize producers of eastern Ethiopia. J. Econ. Struct. 2017, 6, 31. [CrossRef]

78. Goulas, A.; Bourdat-Deschamps, M.; Nélieu, S.; Jimenez, J.; Patureau, D.; Haudin, C.-S.; Benoit, P. Development of a soft extraction method for sulfamethoxazole and transformation products from agricultural soils: Effects of organic matter co-extraction on the environmental availability assessment. Sci. Total Environ. 2017, 607-608, 1037-1048. [CrossRef] [PubMed]

79. Guo, X.; Shen, X.; Zhang, M.; Zhang, H.; Chen, W.; Wang, H.; Koelmans, A.A.; Cornelissen, G.; Tao, S.; Wang, X. Sorption mechanisms of sulfamethazine to soil humin and its subfractions after sequential treatments. Environ. Pollut. 2017, 221, 266-275. [CrossRef]

80. Christl, I.; Ruiz, M.; Schmidt, J.R.; Pedersen, J.A. Clarithromycin and tetracycline binding to soil humic acid in the absence and presence of calcium. Environ. Sci. Technol. 2016, 50, 9933-9942. [CrossRef]

81. Cheng, X.; Hou, H.; Li, R.; Zheng, C.; Liu, H. Adsorption behavior of tetracycline on the soil and molecular insight into the effect of dissolved organic matter on the adsorption. J. Soils Sediments 2020, 20, 1846-1857. [CrossRef]

82. Wang, R.; Yang, S.; Fang, J.; Wang, Z.; Chen, Y.; Zhang, D.; Yang, C. Characterizing the interaction between antibiotics and humic acid by fluorescence quenching method. Int. J. Environ. Res. Public Health 2018, 15, 1458. [CrossRef]

83. Liu, Z.; Han, Y.; Jing, M.; Chen, J. Sorption and transport of sulfonamides in soils amended with wheat straw-derived biochar: Effects of water $\mathrm{pH}$, coexistence copper ion, and dissolved organic matter. J. Soils Sediments 2017, 17, 771-779. [CrossRef]

84. Guo, X.; Tu, B.; Ge, J.; Yang, C.; Song, X.; Dang, Z. Sorption of tylosin and sulfamethazine on solid humic acid. J. Environ. Sci. 2016, 43, 208-215. [CrossRef] [PubMed] 
85. He, Y.; Liu, C.; Tang, X.-Y.; Xian, Q.-S.; Zhang, J.-Q.; Guan, Z. Biochar impacts on sorption-desorption of oxytetracycline and florfenicol in an alkaline farmland soil as affected by field ageing. Sci. Total Environ. 2019, 671, 928-936. [CrossRef]

86. Lai, C.; He, C.; Han, F.; Xu, H.; Huang, B.; Dionysiou, D.D.; Pan, X. Simultaneous changes of exogenous dissolved organic matter treated by ozonation in properties and interaction behavior with sulfonamides. Environ. Pollut. 2021, 275, 116546. [CrossRef] [PubMed]

87. Rizzuto, S.; Baho, D.L.; Jones, K.C.; Zhang, H.; Leu, E.; Nizzetto, L. Binding of waterborne pharmaceutical and personal care products to natural dissolved organic matter. Sci. Total Environ. 2021, 784, 147208. [CrossRef]

88. Pan, B.; Wang, P.; Wu, M.; Li, J.; Zhang, D.; Xiao, D. Sorption kinetics of ofloxacin in soils and mineral particles. Environ. Pollut. 2012, 171, 185-190. [CrossRef] [PubMed]

89. Bai, L.; Zhao, Z.; Wang, C.; Wang, C.; Liu, X.; Jiang, H. Multi-spectroscopic investigation on the complexation of tetracycline with dissolved organic matter derived from algae and macrophyte. Chemosphere 2017, 187, 421-429. [CrossRef] [PubMed]

90. Yang, F.; Zhang, Q.; Jian, H.; Wang, C.; Xing, B.; Sun, H.; Hao, Y. Effect of biochar-derived dissolved organic matter on adsorption of sulfamethoxazole and chloramphenicol. J. Hazard. Mater. 2020, 396, 122598. [CrossRef]

91. Chu, B.; Goyne, K.W.; Anderson, S.H.; Lin, C.-H.; Lerch, R.N. Sulfamethazine Sorption to Soil: Vegetative Management, pH, and Dissolved Organic Matter Effects. J. Environ. Qual. 2013, 42, 794-805. [CrossRef]

92. Fan, W.; Guo, T.; Gao, S.; Lu, Y.; Meng, Y.; Huo, M. Evolution of dissolved organic matter during artificial groundwater recharge with effluent from underutilized WWTP and the resulting facilitated transport effect. Environ. Res. 2021, 193, 110527. [CrossRef]

93. Shen, S.; Yang, S.; Jiang, Q.; Luo, M.; Li, Y.; Yang, C.; Zhang, D. Effect of dissolved organic matter on adsorption of sediments to Oxytetracycline: An insight from zeta potential and DLVO theory. Environ. Sci. Pollut. Res. 2020, 27, 1697-1709. [CrossRef]

94. Li, Y.; Bi, E.; Chen, H. Effects of dissolved humic acid on fluoroquinolones sorption and retention to kaolinite. Ecotox. Environ. Saf. 2019, 178, 43-50. [CrossRef] [PubMed]

95. Lee, J.; Seo, Y.; Essington, M.E. Sorption and transport of veterinary pharmaceuticals in soil—A laboratory study. Soil Sci. Soc. Am. J. 2014, 78, 1531-1543. [CrossRef]

96. Barriuso, E.; Andrades, M.S.; Benoit, P.; Houot, S. Pesticide desorption from soils facilitated by dissolved organic matter coming from composts: Experimental data and modelling approach. Biogeochemistry 2010, 106, 117-133. [CrossRef]

97. Li, K.; Xing, B.; Torello, W.A. Effect of organic fertilizers derived dissolved organic matter on pesticide sorption and leaching. Environ. Pollut. 2005, 134, 187-194. [CrossRef] [PubMed]

98. Xing, Y.; Chen, X.; Wagner, R.E.; Zhuang, J.; Chen, X. Coupled effect of colloids and surface chemical heterogeneity on the transport of antibiotics in porous media. Sci. Total Environ. 2020, 713, 136644. [CrossRef]

99. Sizmur, T.; Fresno, T.; Akgül, G.; Frost, H.; Moreno-Jiménez, E. Biochar modification to enhance sorption of inorganics from water. Bioresour. Technol. 2017, 246, 34-47. [CrossRef]

100. Zhang, P.; Liu, A.; Huang, P.; Min, L.; Sun, H. Sorption and molecular fractionation of biochar-derived dissolved organic matter on ferrihydrite. J. Hazard. Mater. 2020, 392, 122260. [CrossRef]

101. Zhang, L.; Zhu, D.; Wang, H.; Hou, L.; Chen, W. Humic acid-mediated transport of tetracycline and pyrene in saturated porous media. Environ. Toxicol. Chem. 2012, 31, 534-541. [CrossRef]

102. Cheng, W.; Zhou, L.; Marsac, R.; Boily, J.F.; Hanna, K. Effects of organic matter-goethite interactions on reactive transport of nalidixic acid: Column study and modeling. Environ. Res. 2020, 191, 110187. [CrossRef]

103. Gros, M.; Catalán, N.; Mas-Pla, J.; Čelić, M.; Petrović, M.; Farré, M.J. Groundwater antibiotic pollution and its relationship with dissolved organic matter: Identification and environmental implications. Environ. Pollut. 2021, 289, 117927. [CrossRef]

104. Barrios, R.E.; Khuntia, H.K.; Bartelt-Hunt, S.L.; Gilley, J.E.; Schmidt, A.M.; Snow, D.D.; Li, X. Fate and transport of antibiotics and antibiotic resistance genes in runoff and soil as affected by the timing of swine manure slurry application. Sci. Total Environ. 2020, 712, 136505. [CrossRef] [PubMed]

105. Kay, P.; Blackwell, P.A.; Boxall, A.B.A. Transport of veterinary antibiotics in overland flow following the application of slurry to arable land. Chemosphere 2005, 59, 951-959. [CrossRef] [PubMed]

106. Maoz, A.; Chefetz, B. Sorption of the pharmaceuticals carbamazepine and naproxen to dissolved organic matter: Role of structural fractions. Water Res. 2010, 44, 981-989. [CrossRef] [PubMed]

107. Leenheer, J.A. Comprehensive approach to preparative isolation and fractionation of dissolved organic carbon from natural waters and wastewaters. Environ. Sci. Technol. 1981, 15, 578-587. [CrossRef] [PubMed]

108. Leenheer, J.A.; Croué, J.P. Characterizing aquatic dissolved organic matter. Environ. Sci. Technol. 2003, 37, 18-26. [CrossRef]

109. Nebbioso, A.; Piccolo, A. Molecular characterization of dissolved organic matter (DOM): A critical review. Anal. Bioanal. Chem. 2013, 405, 109-124. [CrossRef]

110. Zhao, Z.Y.; Gu, J.D.; Fan, X.J.; Li, H.B. Molecular size distribution of dissolved organic matter in water of the Pearl River and trihalomethane formation characteristics with chlorine and chlorine dioxide treatments. J. Hazard. Mater. 2006, 134, 60-66. [CrossRef]

111. Yan, M.; Korshin, G.; Wang, D.; Cai, Z. Characterization of dissolved organic matter using high-performance liquid chromatography (HPLC)-size exclusion chromatography (SEC) with a multiple wavelength absorbance detector. Chemosphere 2012, 87, 879-885. [CrossRef]

112. Her, N.; Amy, G.; McKnight, D.; Sohn, J.; Yoon, Y. Characterization of DOM as a function of MW by fluorescence EEM and HPLC-SEC using UVA, DOC, and fluorescence detection. Water Res. 2003, 37, 4295-4303. [CrossRef] 
113. Korshin, G.; Chow, C.W.K.; Fabris, R.; Drikas, M. Absorbance spectroscopy-based examination of effects of coagulation on the reactivity of fractions of natural organic matter with varying apparent molecular weights. Water Res. 2009, 43, 1541-1548. [CrossRef]

114. Liang, S.; Lu, L.; Meng, F. DOM-mediated membrane retention of fluoroquinolone as revealed by fluorescence quenching properties. Sci. Rep. 2017, 7, 5372. [CrossRef] [PubMed]

115. Wang, Y.; Zhang, X.; Zhang, X.; Meng, Q.; Gao, F.; Zhang, Y. Characterization of spectral responses of dissolved organic matter (DOM) for atrazine binding during the sorption process onto black soil. Chemosphere 2017, 180, 531-539. [CrossRef]

116. Ferrie, R.P.; Hewitt, G.E.; Anderson, B.D. A fluorescence quenching analysis of the binding of fluoroquinolones to humic acid. Appl. Spectrosc. 2017, 71, 2512-2518. [CrossRef] [PubMed]

117. Yan, P.F.; Hu, Z.H.; Yu, H.Q.; Li, W.H.; Liu, L. Fluorescence quenching effects of antibiotics on the main components of dissolved organic matter. Environ. Sci. Pollut. Res. 2016, 23, 5667-5675. [CrossRef] [PubMed]

118. Hansen, A.M.; Kraus, T.E.C.; Pellerin, B.A.; Fleck, J.A.; Downing, B.D.; Bergamaschi, B.A. Optical properties of dissolved organic matter (DOM): Effects of biological and photolytic degradation. Limnol. Oceanogr. 2016, 61, 1015-1032. [CrossRef]

119. Hur, J.; Williams, M.A.; Schlautman, M.A. Evaluating spectroscopic and chromatographic techniques to resolve dissolved organic matter via end member mixing analysis. Chemosphere 2006, 63, 387-402. [CrossRef] [PubMed]

120. Li, A.; Hu, J.; Li, W.; Zhang, W.; Wang, X. Polarity based fractionation of fulvic acids. Chemosphere 2009, 77, 1419-1426. [CrossRef]

121. Chen, W.; Westerhoff, P.; Leenheer, J.A.; Booksh, K. Fluorescence excitation-emission matrix regional integration to quantify spectra for dissolved organic matter. Environ. Sci. Technol. 2003, 37, 5701-5710. [CrossRef]

122. Hudson, N.; Baker, A.; Reynolds, D. Fluorescence analysis of dissolved organic matter in natural, waste and polluted waters-A review. River Res. Applic. 2007, 23, 631-649. [CrossRef]

123. Fu, Q.L.; He, J.Z.; Blaney, L.; Zhou, D.M. Roxarsone binding to soil-derived dissolved organic matter: Insights from multispectroscopic techniques. Chemosphere 2016, 155, 225-233. [CrossRef]

124. Murphy, K.R.; Stedmon, C.A.; Graeber, D.; Bro, R. Fluorescence spectroscopy and multi-way techniques. PARAFAC. Anal. Methods 2013, 5, 6557-6566. [CrossRef]

125. Yang, B.; Wang, C.; Cheng, X.; Zhang, Y.; Li, W.; Wang, J.; Tian, Z.; Chu, W.; Korshin, G.V.; Guo, H. Interactions between the antibiotic tetracycline and humic acid: Examination of the binding sites, and effects of complexation on the oxidation of tetracycline. Water Res. 2021, 202, 117379. [CrossRef] [PubMed]

126. Yan, C.; Yang, Y.; Zhou, J.; Liu, M.; Nie, M.; Shi, H.; Gu, L. Antibiotics in the surface water of the Yangtze Estuary: Occurrence, distribution and risk assessment. Environ. Pollut. 2013, 175, 22-29. [CrossRef] [PubMed]

127. Zhang, Y.; Wang, Y.; Zhang, X.; Li, R.; Chen, Y.; Meng, Q. Investigating the behavior of binding properties between dissolved organic matter (DOM) and $\mathrm{Pb}$ (II) during the soil sorption process using parallel factor analysis (PARAFAC) and two-dimensional correlation spectroscopy (2D-COS). Environ. Sci. Pollut. Res. 2017, 24, 25156-25165. [CrossRef] [PubMed]

128. Fu, H.; Wei, C.; Qu, X.; Li, H.; Zhu, D. Strong binding of apolar hydrophobic organic contaminants by dissolved black carbon released from biochar: A mechanism of pseudomicelle partition and environmental implications. Environ. Pollut. 2018, 232, 402-410. [CrossRef] [PubMed]

129. Ruiz, S.H.; Wickramasekara, S.; Abrell, L.; Gao, X.; Chefetz, B.; Chorover, J. Complexation of trace organic contaminants with fractionated dissolved organic matter: Implications for mass spectrometric quantification. Chemosphere 2013, 91, 344-350. [CrossRef] [PubMed]

130. Xu, M.; Liu, W.; Bai, Y.; Tu, Y. Complexation of sulfamethazine with typical dissolved organic matter. Acta Sci. Circumstantiae 2018, 38, 4103-4112.

131. Hawkes, J.A.; D’Andrilli, J.; Agar, J.N.; Barrow, M.P.; Berg, S.M.; Catalan, N.; Chen, H.M.; Chu, R.K.; Cole, R.B.; Dittmar, T.; et al. An international laboratory comparison of dissolved organic matter composition by high resolution mass spectrometry: Are we getting the same answer? Limnol. Oceanogr. Meth. 2020, 18, 235-258. [CrossRef]

132. Hawkes, J.A.; Dittmar, T.; Patriarca, C.; Tranvik, L.; Bergquist, J. Evaluation of the orbitrap mass spectrometer for the molecular fingerprinting analysis of natural dissolved organic matter. Anal. Chem. 2016, 88, 7698-7704. [CrossRef]

133. Farré, M.J.; Jaén-Gil, A.; Hawkes, J.; Petrovic, M.; Catalán, N. Orbitrap molecular fingerprint of dissolved organic matter in natural waters and its relationship with NDMA formation potential. Sci. Total Environ. 2019, 670, 1019-1027. [CrossRef]

134. Zhang, X.; Chen, Z.; Huo, X.; Kang, J.; Zhao, S.; Peng, Y.; Deng, F.; Shen, J.; Chu, W. Application of Fourier transform ion cyclotron resonance mass spectrometry in deciphering molecular composition of soil organic matter: A review. Sci. Total Environ. 2021, 756, 144140. [CrossRef] [PubMed]

135. Song, W.; Mu, G.; Zhang, D.; Pan, X. Interaction of acetamiprid with extracellular polymeric substances (EPS) from activated sludge: A fluorescence study. Afr. J. Biotechnol. 2010, 9, 7667-7673.

136. Engebretson, R.R.; von Wandruszka, R. Micro-organization in dissolved humic acids. Environ. Sci. Technol. 1994, $28,1934-1941$. [CrossRef] [PubMed]

137. Jain, A.; Blum, C.; Subramaniam, V. Fluorescence lifetime spectroscopy and imaging of visible fluorescent rroteins. In Advances in Biomedical Engineering; Verdonck, P., Ed.; Elsevier: Amsterdam, The Netherlands, 2009; pp. 147-176.

138. Selim, H.M.; Davidson, J.M.; Mansell, R.S. Evaluation of a two-site adsorption-desorption model for describing solute transport in soil. In Proceedings of the Proc Summer Computer Simulation Conf., Washington, DC, USA, 12-14 July 1976 ; pp. 444-448. 
139. Van Genuchten, M.T.; Wagenet, R.J. Two-site/two-region models for pesticide transport and degradation: Theoretical development and analytical solutions. Soil Sci. Soc. Am. J. 1989, 53, 1303-1310. [CrossRef]

140. Xie, B.; Jiang, Y.; Zhang, Z.; Cao, G.; Sun, H.; Wang, N.; Wang, S. Co-transport of Pb (II) and Cd (II) in saturated porous media: Effects of colloids, flow rate and grain size. Chem. Spec. Bioavailab. 2018, 30, 135-143. [CrossRef]

141. Dai, C.M.; Zhou, H.; You, X.J.; Duan, Y.P.; Tu, Y.J.; Liu, S.G.; Zhou, F.; Hon, L.K. Silica colloids as non-carriers facilitate Pb ${ }^{2+}$ transport in saturated porous media under a weak adsorption condition: Effects of $\mathrm{Pb}^{2+}$ concentrations. Environ. Sci. Pollut. Res. 2020, 27, 15188-15197. [CrossRef]

142. Barton, C.D.; Karathanasis, A.D. Influence of soil colloids on the migration of atrazine and zinc through large soil monoliths. Water Air Soil Poll. 2003, 143, 3-21. [CrossRef]

143. Lindqvist, R.; Enfield, C.G. Biosorption of dichlorodiphenyltrichloroethane and hexachlorobenzene in groundwater and its implications for facilitated transport. Appl. Environ. Microb. 1992, 58, 2211-2218. [CrossRef]

144. Thiele-Bruhn, S. Pharmaceutical antibiotic compounds in soils-A review. J. Plant Nutr. Soil Sci. 2003, 166, 145-167. [CrossRef]

145. Zhou, L.J.; Ying, G.G.; Liu, S.; Zhang, R.Q.; Lai, H.J.; Chen, Z.F.; Pan, C.G. Excretion masses and environmental occurrence of antibiotics in typical swine and dairy cattle farms in China. Sci. Total Environ. 2013, 444, 183-195. [CrossRef]

146. Grindrod, P.; Edwards, M.S.; Higgo, J.J.W.; Williams, G.M. Analysis of colloid and tracer breakthrough curves. J. Contam. Hydrol. 1996, 21, 243-253. [CrossRef]

147. Flury, M.; Qiu, H. Modeling colloid-facilitated contaminant transport in the vadose zone. Vadose Zone J. 2008, 7, 682-697. [CrossRef]

148. Massoudieh, A.; Ginn, T.R. Colloid-facilitated contaminant transport in unsaturated porous media. In Modelling of Pollutants in Complex Environmental Systems; Hanrahan, G., Ed.; ILM Publications: St. Albans, UK, 2010; pp. 259-287.

149. Roy, S.B.; Dzombak, D.A. Sorption nonequilibrium effects on colloid-enhanced transport of hydrophobic organic compounds in porous media. J. Contam. Hydrol. 1998, 30, 179-200. [CrossRef]

150. Corapcioglu, M.Y.; Choi, H. Modeling colloid transport in unsaturated porous media and validation with laboratory column data. Water Resour. Res. 1996, 32, 3437-3449. [CrossRef]

151. Massoudieh, A.; Ginn, T.R. Modeling colloid-facilitated transport of multi-species contaminants in unsaturated porous media. J. Contam. Hydrol. 2007, 92, 162-183. [CrossRef] [PubMed] 